\title{
Landscape-gradient assessment of thermokarst lake hydrology using water isotope tracers
}

Article $\cdot$ November 2016

DOI: $10.1016 /$ j.jhydrol.2016.11.028

CITATIONS

0

5 authors, including:

Biljana Narancic

Laval University

11 PUBLICATIONS 6 CITATIONS

SEE PROFILE

Some of the authors of this publication are also working on these related projects:

Project

Lac St-Charles, Québec View project

All content following this page was uploaded by Biljana Narancic on 26 November 2016.

The user has requested enhancement of the downloaded file. All in-text references underlined in blue are linked to publications on ResearchGate, letting you access and read them immediately. 


\section{Accepted Manuscript}

Research papers

Landscape-gradient assessment of thermokarst lake hydrology using water isotope tracers

Biljana Narancic, Brent B. Wolfe, Reinhard Pienitz, Hanno Meyer, Daniel Lamhonwah

PII: S0022-1694(16)30734-X

DOI: http://dx.doi.org/10.1016/j.jhydrol.2016.11.028

Reference: HYDROL 21642

To appear in: $\quad$ Journal of Hydrology

Received Date: $\quad 19$ May 2016

Revised Date: $\quad 11$ November 2016

Accepted Date: $\quad 14$ November 2016

Please cite this article as: Narancic, B., Wolfe, B.B., Pienitz, R., Meyer, H., Lamhonwah, D., Landscape-gradient assessment of thermokarst lake hydrology using water isotope tracers, Journal of Hydrology (2016), doi: http:// dx.doi.org/10.1016/j.jhydrol.2016.11.028

This is a PDF file of an unedited manuscript that has been accepted for publication. As a service to our customers we are providing this early version of the manuscript. The manuscript will undergo copyediting, typesetting, and review of the resulting proof before it is published in its final form. Please note that during the production process errors may be discovered which could affect the content, and all legal disclaimers that apply to the journal pertain. 
Landscape-gradient assessment of thermokarst lake hydrology using water isotope tracers

$$
\begin{gathered}
\text { Biljana Narancic }^{1} \text {, Brent B. Wolfe }{ }^{2} \text {, Reinhard Pienitz } \\
{ }^{1} \\
\text { Hanno Meyer }{ }^{3} \text { and Daniel Lamhonwah }{ }^{4}
\end{gathered}
$$

${ }^{1}$ Laboratoire de paléoécologie aquatique, Centre d'études nordiques, Département de géographie, Université Laval, QC, G1V 0A6, Canada

${ }^{2}$ Department of Geography and Environmental Studies, Wilfrid Laurier University, Waterloo, ON, N2L 3C5, Canada

${ }^{3}$ Alfred Wegener Institute (AWI) Helmholtz Centre for Polar and Marine Research, Research Unit Potsdam, 14473 Potsdam, Germany

${ }^{4}$ Department of Geography and Planning, Queen's University, Kingston, ON, K7L 3N6, Canada 


\section{HIGHLIGHTS:}

- Water isotopes are used to characterize thermokarst lake hydrology in Nunavik, Canada.

- Rainfall and/or permafrost meltwater are the main lake water sources.

- Maritime climate enhances the hydrological resiliency of thermokarst lakes.

- Terrestrial carbon inputs from surface runoff are likely to increase in the future.

- Thermokarst lakes will persist and methane emissions are likely to increase. 


\section{ABSTRACT}

Thermokarst lakes are widespread in arctic and subarctic regions. In subarctic Québec (Nunavik), they have grown in number and size since the mid- $20^{\text {th }}$ century. Recent studies have identified that these lakes are important sources of greenhouse gases. This is mainly due to the supply of catchment-derived dissolved organic carbon that generates anoxic conditions leading to methane production. To assess the potential role of climate-driven changes in hydrological processes to influence greenhouse-gas emissions, we utilized water isotope tracers to characterize the water balance of thermokarst lakes in Nunavik during three consecutive mid- to late summer seasons (2012-2014). Lake distribution stretches from shrub-tundra overlying discontinuous permafrost in the north to spruce-lichen woodland with sporadic permafrost in the south. Calculation of lake-specific input water isotope compositions $\left(\delta_{\mathrm{I}}\right)$ and lake-specific evaporation-to-inflow $(\mathrm{E} / \mathrm{l})$ ratios based on an isotope-mass balance model reveal a narrow hydrological gradient regardless of diversity in regional landscape characteristics. Nearly all lakes sampled were predominantly fed by rainfall and/or permafrost meltwater, which suppressed the effects of evaporative loss. Only a few lakes in one of the southern sampling locations, which overly highly degraded sporadic permafrost terrain, appear to be susceptible to evaporative lake-level drawdown. We attribute this lake hydrological resiliency to the strong maritime climate in coastal regions of Nunavik. Predicted climate-driven increases in precipitation and permafrost degradation will likely contribute to persistence and expansion of thermokarst lakes throughout the region. If coupled with an increase in terrestrial carbon inputs to thermokarst lakes from surface runoff, conditions favorable for mineralization and 
emission of methane, these water bodies may become even more important sources of greenhouse gases.

Keywords: Nunavik; thermokarst lakes; water isotope tracers; permafrost; water balance; maritime climate

\section{INTRODUCTION}

Numerous shallow thermokarst or 'thaw' lakes develop as a result of rapid permafrost degradation throughout the Arctic and subarctic regions of northern North America (Allard and Séguin, 1987; Payette et al., 2004; Bouchard et al., 2013) and Eurasia (Agafonov et al., 2004). The prerequisite for their formation is the presence and thaw of ground ice. When the depth of seasonal thawing (active layer) exceeds the depth at which ice-rich permafrost occurs, thawing of the perennial frozen layers (permafrost) begins followed by local ground subsidence and water collects in a depression (Pienitz et al., 2008). The latent heat of the water body may further thaw the underlying ground ice, leading to subsidence and deepening of the lake basin.

Permafrost landscapes cover more than $50 \%$ of Canada including $30 \%$ of subarctic Québec (Nunavik; Bouchard et al., 2011). Rapid degradation of permafrost since the mid- $20^{\text {th }}$ century along the eastern coast of Hudson Bay has contributed to an increase in the number of shallow thermokarst lakes (Payette et al., 2004). Thermokarst lakes constitute an important landscape feature and recent studies have documented the global implications of these aquatic ecosystems as a potential source of greenhouse gases, especially methane (Laurion et al., 2010; Comte et al., 2015; Crevecoeur et al., 2015; Deshpande et al., 2015; Przytulska et al., 2015). They are rich in dissolved 
organic carbon (DOC), most of which originates from thawing permafrost. Laurion et al. (2010) found that some lakes demonstrate strong thermal stratification due to high DOC concentrations. As a result, most of the lakes have anoxic bottom waters despite their shallow depth $(<5 \mathrm{~m})$. This chemical gradient of oxygen, with an upper oxic and bottom anoxic layer, represents an ideal environment for anaerobic processes such as methane production (Laurion et al., 2010; Deshpande et al., 2015; Matveev et al., 2016). During water column mixing, methane is released to the atmosphere. Consequently, thermokarst lakes (and their influence on atmospheric methane concentrations) are expected to play a major role in future climate change (Wik et al., 2016).

Based on the Canadian Regional Climate Model (CRCM), Nunavik is expected to experience $3{ }^{\circ} \mathrm{C}$ warming in winter air temperature and $1.5^{\circ} \mathrm{C}$ warming in summer air temperature, along with a $25 \%$ increase in total annual precipitation by 2050 (Brown et al., 2012). Changes in temperature and precipitation, combined with permafrost thaw, may increase soil-derived DOC supply via runoff and enhanced hydrological connectivity, possibly further promoting stratification and greenhouse-gas production in thermokarst lakes. Hydrological changes induced by climate change might have additional influence on limnological properties and biogeochemical cycling of these lakes, yet little is known about the hydrological processes that influence thermokarst lake water balance conditions in this region. Recent isotope-based studies from the western Hudson Bay Lowlands (Wolfe et al., 2011, Bouchard et al., 2013), Old Crow Flats (Tondu et al., 2013; Turner et al., 2010, 2014), Yukon Flats (Anderson et al., 2013) and northern Alberta (Gibson et al., 2015, 2016a) concluded that shallow thermokarst lakes are hydrologically dynamic systems yielding a great diversity of lake water balance 
conditions, variably influenced by hydrological processes (snowmelt, rainfall, permafrost meltwater, evaporation) and catchment features (vegetation, topography; Table 1). The stable isotope mass balance approach has also been used to characterize the influence of hydrological processes on non-thermokarst northern lakes (Gibson and Reid, 2014; Gibson et al., 2015; Gibson et al., 2016b) and on lakes elsewhere (Steinman et al., 2013; Jones et al., 2016).

$<$ Table 1 here please $>$

In this study, our aim is to identify and quantify the diversity of hydrological processes that control thermokarst lake water balances in Nunavik. Our approach was to sample lakes with different physical characteristics (color, depth, size, catchment vegetation) across vast landscape gradients from subarctic to arctic environments during a three-year sampling campaign (2012-2014) to capture the range of hydrological conditions. The main objectives of the study were to apply an isotope-mass balance model to: 1) determine lake-specific input water isotope compositions $\left(\delta_{l}\right)$ to identify the roles of primary source waters (e.g., rainfall, snowmelt and permafrost meltwater); and 2) calculate lake-specific evaporation-to-inflow (E/I) ratios to evaluate the influence of vapor loss. Results obtained provide the basis to anticipate hydrological responses and their influence on greenhouse gas behavior of thermokarst lakes to rapidly changing climate at the regional scale.

\section{STUDY REGION}

The study region is located on the eastern coast of Hudson Bay, Canada, and 
comprises four distinctive sites (Fig. 1). The two northern sites are located near the Umiujaq village: Nastapoka River valley (NAS; $56^{\circ} 55.423^{\prime} \mathrm{N}, 76^{\circ} 22.750^{\prime} \mathrm{W}$ ) and Sheldrake River valley (BGR; 56³6.652' N, 76¹2.912' W). Two southern sites are located near the village of Whapmagoostui-Kuujjuarapik (W-K): Kwakwabtanikapistikw River valley (KWK; 55¹9.853' N, 77³0.166' W) and Sasapimakwananisikw River valley

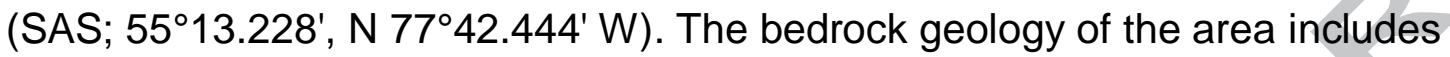
Precambrian granites and gneisses overlain by Quaternary glacial, glaciofluvial and marine deposits. The region was submerged by the postglacial Tyrrell Sea until ca. 6000 cal. BP following the last regional deglaciation ca. 8000 cal. BP (Pienitz et al., 1991; Saulnier-Talbot et al., 2007) that left thick deposits of marine silts and clays in valleys. These poorly-drained valley floors covered with marine clay induced the development of wetlands with peat plateaus supporting trees and shrubs (ca. 5000 cal. BP). Climate cooling during the Neoglacial period ( $\sim 3200 \mathrm{BP})$ led to a decrease in peat accumulation and drying of the soil surface due to growth of ground ice (Allard and K.-Seguin, 1987). During the cold and dry climate of the Little Ice Age, permafrost reached its maximum extent ( 500 BP; Allard and K.-Séguin, 1987; Calmels et al., 2008). Presence of permafrost is easily assessed in this landscape as it forms mounds of organic-rich palsas and mineral lithalsas that coexist within a few tens of meters of each other. Climate warming during recent decades has led to increasingly rapid thawing of permafrost mounds and transformation of the landscape into a mosaic of colorful shallow thermokarst lakes (Payette et al., 2004; Fig. 2). The color variability originates from permafrost thaw in surrounding soils and ranges from white to green in lakes with high concentrations of suspended fine clay particles, to brown and black in lakes rich in DOC (Laurion et al., 2010; Comte et al., 2015; Crevecoeur et al., 2015; Przytulska et al., 
2015).

$<$ Figure 1 and 2 here please $>$

The study lakes are distributed along a north-south latitudinal, vegetation and permafrost gradient (Fig.1 and 2). Lakes in the northern sites, NAS and BGR, are situated in the transitional boreal/arctic tundra zone dominated by shrub tundra vegetation and scattered forest overlying discontinuous permafrost and marine silts of low permeability. The arctic tundra zone has almost no trees; sheltered locations contain mainly Betula glandulosa shrubs. The dominant vegetation in the boreal-subarctic zone includes spruce trees (Picea mariana, P. glauca), tall shrubs (Betula glandulosa, Salix planifolia), mosses (Sphagnum spp.) and herbaceous plants (Carex spp). At the time of field work, sampled lakes at BGR where distinctly colored and unlikely to have been influenced recently by the nearby river (Fig. 2). The southern KWK and SAS are situated in the boreal-subarctic zone within spruce-lichen woodland overlying sporadic permafrost. Lakes at KWK are located on postglacial marine clay soils of low permeability covered with dense forest and shrub vegetation where local permafrost is at an advanced stage of degradation (Bouchard et al., 2011). The elevation of the lakes at KWK are well above the nearby creek shown in Figure 2. Lakes at SAS are located in peatlands within rapidly degrading permafrost mounds (Bhiry and Robert, 2006). The landscape is relatively flat at SAS and BGR, whereas slight topographic relief exists at NAS and KWK sites owing to rocky hills and steep trenches. Low permeability of finegrained substrate, presence of permafrost and generally low relief likely restrict hydrological surface and subsurface connectivity between lakes. 
The climate is influenced by the proximity of Hudson Bay. The farthest inland site (BGR) is located approximately $20 \mathrm{~km}$ from Hudson Bay. Once the bay freezes, the climate becomes dry continental with low temperatures (Dec-Feb $=-19.5^{\circ} \mathrm{C}$ mean) and when ice retreats, maritime conditions with frequent dense fogs occur in the summer (Jun-Aug $=9.5^{\circ} \mathrm{C}$ mean). Mean annual temperature and total precipitation for the three-

year sampling period were above the 55-year regional long-term means (Table 2). There were some seasonal differences with more rainfall in 2014 than during the previous two years whereas snowfall was less than the long-term mean during 2012 and similar to the 2013 and 2014 means. The summer relative humidity for 2012-2014 ranged from 77.2 $\%$ to $80.4 \%$, close to the 55-year regional mean ( $80 \%$; Environment Canada, 2015) $<$ Table 2 here please $>$.

\section{MATERIALS AND METHODS}

\subsection{Field sampling and analysis}

To address the objectives, water samples were collected from precipitation, permafrost cores and lakes. As the Global Network of Isotopes in Precipitation (GNIP) has no station in the Nunavik region, there was a need for year-round precipitation sampling for isotope analysis which was performed at the Centre for Northern Studies (CEN) station in W-K. In total, forty precipitation samples were collected from September 2013 to August 2014 on a per precipitation-event. Rainwater was collected in a plastic pan attached to a laundry line until enough was gathered to fill a 30-ml high-density polyethylene bottle. This took less than 6 hours. Snow samples were collected in Ziploc bags shortly after it fell and once completely melted, the meltwater was transferred to 30-ml high-density polyethylene bottles. Precipitation samples were analyzed for oxygen 
and hydrogen isotope composition at the Alfred-Wegener Institute for Polar and Marine Research in Potsdam (Germany) following the methods outlined in Meyer et al. (2000).

Four permafrost cores (BGR-A [2.4 m], BGR-B [2.3 m], SAS-A [2.3 m] and SAS-B [2.4 m] obtained in August 2013 were sectioned ( 10 cm long segments) in the freezer room $\left(-15\right.$ to $\left.-13^{\circ} \mathrm{C}\right)$ at CEN (Université Laval) using a mitre saw. Cores were split in two using an ice chisel, and subsamples were taken from the interior of each core. A razor was used to remove the exterior of each subsample $(\sim 5 \mathrm{~mm})$ to prevent contamination. In total, six ice samples from cores BGR-A and SAS-B, eight ice samples from core BGR-B and five ice samples from core SAS-A were placed in conical tubes and spun in a centrifuge at 3300 RPM to separate water from sediment, and then filtered with a 0.22 micrometer PVDF syringe filter. The oxygen and hydrogen isotope compositions on water were measured by laser absorption technology using a Los Gatos Research liquid water isotope analyzer at Queen's University (Kingston, Ontario).

Surface lake water samples were collected in 30-ml high-density polyethylene bottles close to the center of each lake for isotope analysis. In total, 17 lakes were sampled from all four sites in 2012 (25-30 August; 5 at NAS and 4 at BGR, KWK and SAS), 86 in 2013 (30 July-6 August; 12 at NAS, 17 at BGR, 35 at KWK and 22 at SAS) and 82 in 2014 (25-30 August; 12 at NAS, 15 at BGR, 33 at KWK and 22 at SAS). Due to the small number of lakes sampled in 2012, we focus mainly on results obtained for the last two sampling years. Due to logistical constraints in the field, four lakes were not sampled in 2014 (BGR HELIP., BGR O, KWK 17 and KWK 38/39). 
Samples were stored at $4{ }^{\circ} \mathrm{C}$ prior to analysis at the University of Waterloo Environmental Isotope Laboratory for oxygen and hydrogen isotope composition. Samples collected in 2012 and 2013 were analyzed by continuous flow isotope ratio mass spectrometry using conventional techniques (Epstein and Mayeda, 1953; Morrison et al., 2001), whereas samples collected in 2014 were analyzed by laser absorption technology using a Los Gatos Research liquid water isotope analyzer.

Isotope compositions are expressed as $\delta$-values relative to Vienna Standard Mean Ocean Water (VSMOW) in per mil (\%o), such that $\delta_{\text {sample }}=\left(R_{\text {sample }}-R_{\text {VSMOW }}\right) /$ $\mathrm{R}_{\text {VSMOW }} \times 1000$ where $\mathrm{R}$ is the ratio ${ }^{18} \mathrm{O} /{ }^{16} \mathrm{O}$ or $\mathrm{D} /{ }^{1} \mathrm{H}$ in the sample and VSMOW. Results of $\delta^{18} \mathrm{O}$ and $\delta \mathrm{D}$ analysis are normalized to $-55.5 \%$ and $-428 \%$, respectively, for Standard Light Antarctic Precipitation (SLAP; Coplen, 1996). Analytical uncertainties are $\pm 0.2 \%$ for $\delta^{18} \mathrm{O}$ and \pm 2.0 for $\delta \mathrm{D}$ for lake water samples analyzed by continuous flow mass spectrometry (2012 and 2013) and $\pm 0.2 \%$ for $\delta^{18} \mathrm{O}$ and $\pm 0.8 \%$ for $\delta \mathrm{D}$ for those analyzed by laser absorption (2014). Precipitation isotope compositions have an analytical precision of $\pm 0.1 \%$ for $\delta^{18} \mathrm{O}$ and $\pm 0.8 \%$ for $\delta \mathrm{D}$, and permafrost isotope compositions have an analytical precision of $\pm 0.2 \%$ for $\delta^{18} \mathrm{O}$ and $\pm 0.8 \%$ for $\delta \mathrm{D}$.

3.2. Stable isotope mass-balance modelling

Lake hydrological conditions were evaluated using a reference isotope framework in $\delta^{18} \mathrm{O}-\delta \mathrm{D}$ space consisting of the Global Meteoric Water Line (GMWL) and the Local Evaporation Line $(L E L)$. The GMWL $\left(\delta D=8 \delta^{18} \mathrm{O}+10\right)$ expresses the linear relationship between the oxygen and hydrogen isotope compositions of precipitation globally (Craig, 
1961). The $\delta^{18} \mathrm{O}$ and $\delta \mathrm{D}$ values for precipitation fall along the GMWL, and their position reflects variability in spatial and seasonal trajectory of the atmospheric vapor contributing to local precipitation (Rozanski et al., 1993). This leads to isotopicallydepleted winter precipitation and isotopically-enriched summer precipitation (Dansgaard, 1964). Lake surface water, as any other open water body undergoing evaporation, will deviate isotopically from the GMWL owing to mass-dependent fractionation. The LEL diverges from the GMWL on a slope typically between 4 and 6 depending on the local atmospheric conditions, including relative humidity (rh), temperature $(T)$ and isotope composition of the summer atmospheric moisture ( $\delta_{\mathrm{AS}}$; Yi et al., 2008). The LEL for a given region generally represents the expected linear trajectory of evaporative isotopic enrichment of a lake fed by the weighted average annual isotope composition of local precipitation $\left(\delta_{\mathrm{P}}\right)$. Here we differentiate and utilize the 'predicted' LEL based on the linear resistance model of Craig and Gordon (1965) and used elsewhere (e.g., Wolfe et al., 2011; Turner et al., 2014), from the more commonly applied 'empirically-defined' LEL for a given region based on linear regression through a series of lake water isotope compositions. The advantage of the former is that it permits lake water isotope compositions to be interpreted independently. Thus, we interpret deviation of lake water isotope composition from the predicted $L E L$ to be due to the differing relative influence of source waters such as rainfall, snowmelt and permafrost meltwater. The location of the lake water isotope composition along the predicted LEL reflects the degree of evaporation. 
To quantitatively assess components of the lake water balances, we used lake water isotope compositions $\left(\delta_{\mathrm{L}}\right)$ to calculate lake-specific input water $\left(\delta_{\mathrm{I}}\right)$ and evaporation-to-inflow (E/I) ratios for each lake at the time of sampling (see Appendix). These metrics provide information regarding the nature of source water (rainfall, snowmelt, permafrost meltwater) and the intensity of evaporation for each lake at the time of sampling. We derived these metrics utilizing the coupled-isotope tracer method of Yi et al. (2008). This method is based on the linear resistant model of Craig and Gordon (1965) and has previously been utilized by Tondu et al. (2013) and Turner et al. $(2010,2014)$ in water balance studies of thermokarst lakes. The $\delta_{l}$ value for each lake water isotope composition was estimated by calculating a lake-specific LEL and identifying its intersection with the GMWL. The lake-specific LEL extends between measured $\delta_{\mathrm{L}}$ and the evaporated flux from the individual lake $\left(\delta_{\mathrm{E}}\right)$ calculated using Craig and Gordon (1965) model (See Appendix, Eq. A10). $\delta_{\mathrm{E}}$ lies on the extension of the lakespecific LEL to the left of the GMWL. The relative importance of lake source water origin, rainfall and permafrost meltwater (isotopically-enriched) and/or snowmelt (isotopically-depleted) as reported below, was estimated by the $\delta_{\mathrm{I}}$ position on the GMWL relative to $\delta_{\mathrm{p}}$ such that $\delta_{\mathrm{l}}>\delta_{\mathrm{p}}$ is isotopically-enriched and $\delta_{\mathrm{l}}<\delta_{\mathrm{P}}$ isotopically-depleted. The $E / /$ ratio for each lake at the time of sampling was calculated (Eq. A9) assuming isotopic and hydrologic steady-state conditions.

\section{RESULTS}

\subsection{Development of isotope framework}

Forty precipitation samples from $\mathrm{W}-\mathrm{K}$ yield a maximum $\delta^{18} \mathrm{O}$ value of $-7.9 \%$ and 
$-62.3 \%$ for $\delta \mathrm{D}$ (recorded August $27^{\text {th }}, 2014$ ), a minimum $\delta^{18} \mathrm{O}$ value of $-39.3 \%$ and $-295.4 \%$ for $\delta \mathrm{D}$ (January $\left.1^{\text {st }}, 2014\right)$, and a non-weighted mean annual isotope composition $\left(\delta_{\mathrm{P}}\right)$ of $-17.1 \%$ for $\delta^{18} \mathrm{O}$ and $-126.8 \%$ for $\delta \mathrm{D}$ (Fig. 3, Table 3 ). The isotope composition of snow ranges from $-39.3 \%$ to $-9.9 \%$ for $\delta^{18} \mathrm{O}(-295.5 \%$ to $-70.0 \%$ for $\delta \mathrm{D})$, whereas rain ranges from $-15.8 \%$ to $-7.9 \%$ for $\delta^{18} \mathrm{O}(-122.6 \%$ to $-62.3 \%$ for $\delta \mathrm{D})$. The isotope composition of permafrost meltwater ranges from $-17.4 \%$ to $-10.9 \%$ for $\delta^{18} \mathrm{O}(-123.9 \%$ to $-81.4 \%$ for $\delta \mathrm{D})$ with mean values of $-14.2 \%$ for $\delta^{18} \mathrm{O}$ and $-120.8 \%$ for $\delta \mathrm{D}$ (Table 4). As expected, the snow samples plot along an isotopically-depleted portion of the GMWL relative to rain. The permafrost meltwater isotope compositions overlap with rain isotope compositions on the GMWL, suggesting permafrost meltwaters are largely sourced by infiltration of rainfall. Overall, the isotope compositions of all precipitation and permafrost samples fall along the GMWL, as expected for water that has not undergone secondary evaporative enrichment. Thus, the GMWL offers a reasonable representation for isotope composition of precipitation in the study region, and justifies using the GMWL as a baseline for determining source water isotope compositions $\left(\delta_{1}\right)$ to lakes.

$<$ Figure 3 here please $>$ and $<$ Tables 3 and 4 here please $>$

Two predicted LELs were developed as study sites are located in different biogeographical and climate zones (Fig. 4, Table 5). The Umiujaq LEL was developed for the northern sites (BGR and NAS) and the W-K LEL for the southern sites (SAS and KWK). Both LELs are anchored to the GMWL at $\delta p=-17.1 \%$ for $\delta^{18} \mathrm{O}(-126.8 \%$ for $\delta D)$, derived from the non-weighted mean of year-round precipitation samples from $\mathrm{W}-\mathrm{K}$. The 
other reference points along the LELs include the limiting steady-state isotope composition $\left(\delta_{\mathrm{SSL}}\right)$ where inflow equals evaporation $(\mathrm{I}=\mathrm{E})$, as well as the theoretical limiting isotopic enrichment $\left(\delta^{*}\right)$ that marks extreme non-steady-state behavior and which depends entirely on local atmospheric conditions (see Appendix; Table 5). Given the consistency of flux-weighted temperature and relative humidity during the three-year period (Table 5a), a three-year mean of all parameters was used to define the predicted LELs (Umiujaq LEL: $\delta \mathrm{D}=5.2 \delta^{18} \mathrm{O}-38.9 ; \mathrm{W}-\mathrm{K}$ LEL: $\delta \mathrm{D}=5.1 \delta^{18} \mathrm{O}-39.1$ ). Both predicted LELs are nearly identical, thus, $\delta_{\mathrm{L}}$ values from all four sites are superimposed on the predicted three-year mean W-K LEL.

$<$ Figure 4 here please $>$ and $<$ Table 5 here please $>$

\subsection{Lake water isotope compositions}

Lake water isotope compositions $\left(\delta_{\mathrm{L}}\right)$ from each site and from each sampling period are superimposed on the isotope framework to identify inter-annual and sitespecific variability in hydrological conditions (Fig. 5, Table S1). The isotope compositions of NAS lakes extend along a rather weak linear trend compared to the other sites $\left(r^{2}=\right.$ $0.70 ;-13.8 \%$ to $-9.5 \%$ for $\delta^{18} \mathrm{O}$ and $-104.2 \%$ to $-82.7 \%$ for $\delta \mathrm{D}$ ), and several cluster close to the GMWL (Fig. 5a). The isotope compositions of BGR lakes extend along a strong linear trend $\left(r^{2}=0.98 ;-13.9 \%\right.$ to $-9.1 \%$ for $\delta^{18} O$ and $-107.1 \%$ to $-80.7 \%$ for $\left.\delta D\right)$ above the predicted LEL (Fig 5b). The isotope compositions of BGR lakes span a considerable range along the predicted LEL, indicating varying evaporative isotopic enrichment, although none of the lakes plot beyond $\delta_{\text {SSL. }}$. The isotope compositions of KWK extend along a linear trend $\left(r^{2}=0.82 ;-12.9 \%\right.$ to $-7.8 \%$ for $\delta^{18} \mathrm{O}$ and $-97.6 \%$ to - 
$72.5 \%$ for $\delta \mathrm{D}$ ) above and generally further along the predicted LEL compared to lakes from the other sites, indicating greater evaporative enrichment with some lakes plotting beyond $\delta_{\text {ssL }}$ (Fig. 5c). Only one lake, KWK 14 (2014), falls below the predicted LEL. The isotope compositions of SAS lakes plot along a linear trend (mean $r^{2}=0.80 ;-13.5 \%$ to $9.7 \%$ for $\delta^{18} \mathrm{O}$ and $-102.1 \%$ to $-80.9 \%$ for $\delta \mathrm{D}$ ) extending to the right from the GMWL and above the predicted LEL (Fig. 5d). Many SAS lakes cluster close to the GMWL. Although a few lakes suggest more substantial lake water evaporative isotopic enrichment, none of the lakes plot beyond $\delta_{S S L}$. Considering all sites, there are no substantial inter-annual fluctuations in the isotope composition of lake waters as expected due to the similar meteorological conditions. Nearly all $\delta_{\mathrm{L}}$ values plot above the predicted LEL revealing predominantly rainfall and/or permafrost meltwater influence on water balances. Many of the lakes cluster close to or directly on the GMWL, indicating a small degree of evaporative isotopic enrichment although this appears greatest for KWK lakes. Lake-specific source waters and the degree of evaporative isotopic enrichment are characterized further with calculation of $\delta_{\mid}$and $E / /$ values, as reported in the next section.

$<$ Figure 5 here please $>$

\subsection{Water-balance metrics}

Lake-specific input water isotope compositions $\left(\delta_{1}\right)$ were calculated for 2013 and 2014 to quantitatively evaluate the relative role of rainfall, snowmelt and permafrost meltwater on lake hydrological conditions (Fig. 6, Table S1). For the NAS lakes, $\delta_{I}$ values range from $-15.5 \%$ to $-12.5 \%$ for $\delta^{18} \mathrm{O}$ and $-113.8 \%$ to $-90.0 \%$ for $\delta \mathrm{D}$ and for 
BGR lakes, $\delta_{1}$ values range from $-15.6 \%$ to $-13.4 \%$ for $\delta^{18} \mathrm{O}$ and $-114.8 \%$ to $-97.5 \%$ for $\delta \mathrm{D}$ (Fig. $6 \mathrm{a}$ and b). $\delta_{1}$ values indicate rather consistent relative influence of rainfall and/or permafrost meltwater on the lake water balances for both sites and for both years. $\delta_{\mid}$values for the KWK dataset range from $-16.2 \%$ to $-12.6 \%$ for $\delta^{18} \mathrm{O}$ and -119.5 $\%$ to $-91.2 \%$ for $\delta \mathrm{D}$ (Fig. 6c). Higher degree of source water variability is evident in 2013 compared to 2014. For KWK lakes, $\delta_{\mid}$values for 2014 are more isotopicallyenriched than in 2013. The $\delta_{l}$ values increased for almost all lakes, averaging $0.8 \%$ for $\delta^{18} \mathrm{O}$ and $6.3 \%$ for $\delta \mathrm{D}$. Only one lake from this dataset, KWK 14 , has a $\delta_{\mathrm{I}}$ value plotting below $\delta_{\mathrm{P}}$ on the GMWL (-17.5\% for $\delta^{18} \mathrm{O}$ and $-130.0 \%$ for $\delta \mathrm{D}$ in 2014$)$, reflecting snowmelt as the predominant source water. $\delta_{1}$ values for the SAS dataset range from $15.9 \%$ to $-12.4 \%$ for $\delta^{18} \mathrm{O}$ and $-120.4 \%$ to $-88.9 \%$ for $\delta \mathrm{D}$ (Fig. $6 \mathrm{~d}$ ). $\delta_{\mathrm{l}}$ values for 2013 indicate a high degree of variability of the relative influence of rainfall and/or permafrost meltwater on the lake water balances. In contrast, $\delta_{l}$ values for 2014 vary less, but are similarly positioned on the GMWL with respect to rainfall and/or permafrost meltwater. Overall, $\delta_{\mathrm{I}}$ values for nearly all lakes are more enriched than $\delta_{\mathrm{P}}$ indicating that at the time of sampling, lakes were predominantly sourced by rainfall and/or permafrost meltwater. $<$ Figure 6 here please $>$

Evaporation-to-inflow (E/I) ratios for 2013 and 2014 were determined to quantify the importance of evaporative processes for individual lake water balances (Fig. 7, Table S1). E/I ratios for NAS and BGR lakes range from 0.00 to 0.30 and from 0.02 to 0.52 , respectively, indicative of positive water balances for both sites. For KWK lakes, E/I ratios range much more substantially from 0.03 to 0.96 , but all possess positive 
water balances. Three lakes have particularly high E/I ratios: KWK $6(0.71), 23(0.80)$ and $18(0.96)$. E/I ratios for the SAS site range from 0.00 to 0.23 indicating strongly positive water balances for this site as well. For all sites, E/I ratios are similar for the two years, although several E/I ratios are slightly to substantially higher for KWK and SAS in 2013. Overall, E/I ratios are the highest for KWK and BGR lakes and lowest for SAS and NAS lakes. Based on E/I ratios, the majority of sampled lakes have rather low evaporative influence $(E / I<0.5)$, except for a few lakes at KWK. $<$ Figure 7 here please $>$

\section{DISCUSSION}

Mid- to late summer snapshots of lake water isotope compositions, and derived $\delta_{1}$ and $\mathrm{E} / \mathrm{I}$ values, provide insights into hydrological processes that influence individual thermokarst lake water balances across large latitudinal, vegetation and permafrost gradients. Remarkably, despite these large gradients, lakes span a comparatively narrow range of isotope composition and display a mostly consistent low degree of evaporative enrichment. Furthermore, the isotope compositions of lakes consistently plotted above the regional predicted LEL, corresponding to relatively high $\delta_{l}$ values, reflecting the relative importance of rainfall and/or permafrost meltwater on their water balances (Fig. 5). Since the rainfall and permafrost-meltwater isotope compositions overlap on the GMWL (Fig. 3), we are unable to determine the relative contributions of these two lake water sources based on these data alone. Similarly, isotope analyses in Yukon Flats, Alaska, were unable to distinguish the influence of permafrost meltwater from snowmelt for a small group of lakes that plotted on a distinctly lower LEL compared 
to most other lakes sampled (Anderson et al., 2013). In contrast to other studies (e.g., Turner et al., 2010, 2014; Tondu et al., 2013), we did not observe that lakes situated in catchments with high proportions of woodland/forest and tall shrub vegetation receive substantial snowmelt inputs. Seasonal observations from automated time-lapse cameras of lake ice and snow cover reveal that lakes and surrounding catchments are free of ice and snow cover approximately at the same time (in first two weeks of June) regardless of their latitudinal position (Pienitz et al., 2016). Thus, we suggest that substantial mid-summer rainfall in 2013 and 2014 (Table 2), and timing of mid- to late summer sampling, led to the strong influence of rainfall on lake water isotope compositions, which overwhelmed ability to detect the effects of snowmelt runoff.

Quantitative estimation of evaporation-to-inflow (E/l) ratios indicates that evaporation tends to be a small component of lake water balances for a majority of the thermokarst lakes (mean $E / l$ for all sampled lakes $=0.15 \pm 0.1 \mathrm{SD}$ ). Consistent with these results, there were no signs of thermokarst lake desiccation during mid-summer as observed in the northwestern Hudson Bay Lowlands (northern Manitoba, Canada; Bouchard et al., 2013) and Old Crow Flats (Yukon Territory, Canada; Turner et al., 2010). An isotopebased synthesis of thermokarst lake water balances (MacDonald et al., accepted) underscores the resilience of Nunavik thermokarst lakes to evaporation in relation to other permafrost landscapes in northern North America that have abundant thermokarst lakes. Low influence of evaporation on thermokarst lakes in Nunavik is likely due to the maritime climate in coastal regions during summer months that results in regular and evenly dispersed precipitation. Similarly, in Greenland, maritime climate ensures low 
rates of evaporation in coastal regions compared to inland lakes (Leng et al., 2003). Based on Table 2, considerable mid-summer rainfall likely further dampened the effects of evaporation on the lake water balances, although apparently less so for KWK and SAS in 2013 consistent with less rainfall during this year compared to 2014 .

Although $\delta_{1}$ results alone cannot readily distinguish the influence of rainfall versus permafrost meltwaters on lake water balances, there appears to be some correspondence between E/I among the study sites and degree of permafrost degradation (Fig. 7). KWK lakes possessed the highest E/l ratios, and among the four study sites, KWK is the only one with highly degraded permafrost; in fact, there is almost no permafrost left at this site (M. Allard, pers. comm.). As a result, KWK lakes are potentially most vulnerable to become evaporation-dominated if permafrost meltwaters no longer provide an additional source of water to offset evaporation. Such conjecture is supported by Gibson et al. (2015), who identified that water isotope composition of thermokarst lakes that receive permafrost meltwater tend to be less evaporatively enriched. Perhaps the few lakes that have high E/I ratios are at the leading edge of this potential hydrological transition, which may have been suppressed during the years in which we conducted our study based on the high rainfall and timing of our sampling. Although lakes from other sites still potentially receive water inputs from permafrost meltwaters and undoubtedly from rainfall, permafrost degradation and loss of this water input could enhance the effects of evaporation. However, expected climate projections for the Nunavik region include a $25 \%$ increase in annual precipitation (Brown et al., 2012), which will in all likelihood buffer any potential lake evaporation effects due to the 
decrease in permafrost meltwater inputs and increase the persistence of these lakes in the region. Such changes may already be occurring in western Siberia. Agafonov et al. (2004) suggested that expansion of thermokarst lakes during the past 50 years is largely a result of increasing precipitation.

Our assessment of thermokarst lake hydrological conditions and forecast of future hydrological trajectories assumes the basins are hydrologically-closed, which is reasonable given the low relief, fine-grained substrate and varying presence of permafrost that likely limits surface and subsurface hydrological connectivity. In the western Hudson Bay Lowlands, diverging hydrological responses of shallow thermokarst lakes to recent climate change has been largely attributed to the degree of hydrological connectivity (Wolfe et al., 2011; Bouchard et al., 2013). In Nunavik, permafrost thaw may induce greater subsurface hydrological connectivity, which would most likely serve to further enhance the dominance of lake inflow versus evaporation and lake persistence that is evident in our results. However, strong evaporative isotopic enrichment at some thermokarst lakes in the permafrost-degraded KWK site would seem to suggest that, for at least this location, increased hydrological connectivity may not be an outcome of permafrost thaw owing to postglacial marine clay substrate of low permeability.

Catchment-derived water from rainfall and permafrost-thaw are rich in dissolved and particulate substances that promote chemical stratification in thermokarst lakes in Nunavik (Laurion et al., 2010; Matveev, et al., 2016). Given future projected increases in precipitation, additional terrestrial input associated with accelerated permafrost 
degradation may consequently enhance the potential for methane production in anoxic bottom waters of these thermokarst lakes (Matveev et al., 2016). Thus, methane production and emission from Nunavik lakes may become even more substantial than current estimates (Wik et al., 2016). More extensive intra- and inter-annual hydrological, limnological and biogeochemical sampling and analysis should shed further light on these relations.

\section{CONCLUSION}

Water isotope analyses of thermokarst lakes across large latitudinal, vegetation and permafrost gradients in Nunavik, supplemented by isotope analyses of precipitation and permafrost meltwater, reveal a narrow range of lake water balance conditions. Calculation of water balance metrics, including the isotope composition of input water and evaporation-to-inflow ratios, indicate that most lakes, at the time of sampling, were sourced by rainfall and/or permafrost meltwater and had experienced low degree of evaporation. We attribute these results to the maritime climate in the coastal region of Nunavik, which plays an over-riding influence on lake hydrology, evidently dampening potential hydrological influence stemming from differences in catchment vegetation and permafrost condition. Consequently, the maritime climate renders these thermokarst lakes to be resilient to the effects of evaporation. Given future increases in precipitation, we expect thermokarst lakes to be even less influenced by evaporation and perhaps grow in number and water body size, occupying an increasingly significant surface area, with the exception of landscapes where permafrost has almost disappeared (e.g., KWK). If projected increases in precipitation coupled with accelerated permafrost degradation in the region yield greater transport and supply of DOC to lakes, this may enhance the 
role of these lakes as greenhouse-gas emitters.

\section{ACKNOWLEDGEMENTS}

This work is part of a Ph.D. research project by B. Narancic funded through a Discovery Research grant awarded to R. Pienitz from the Natural Sciences and Engineering Research Council (NSERC) of Canada, the Arctic Development and Adaptation to Permafrost in Transition (ADAPT), the NSERC-CREATE EnviroNord training program in Northern Environmental Sciences, as well as logistic support from Center for Northern Studies (CEN). We would like to express our gratitude to Claude Tremblay of the CEN Research Station in W-K for his dedicated work in precipitation sampling. We would also like to thank Frédéric Bouchard, Valentin Proult and Denis Sarrazin for their assistance in the field. We are grateful to Émilie Saulnier-Talbot for inspiring discussions and Claudia Zimmermann for help in the laboratory. We thank laboratory personnel of the University of Waterloo - Environmental Isotope Laboratory and from Alfred Wegener Institute (AWI) for their support in lake water sample analysis. We would also like to thank two anonymous reviewers, as well as the associate editor and editor, whose comments have led to many improvements. 


\section{APPENDIX}

Calculation of $\delta$ SSL and $\delta^{*}$ :

$\delta_{\text {ssL }}$ represents the isotope composition of a terminal basin, where evaporation is equal to inflow, and was determined using the expression from Gonfiantini (1986):

$\delta_{S S L}=\alpha^{*} \delta_{l}\left(1-h+\varepsilon_{k}\right)+\alpha^{*} h \delta_{A S}+\alpha^{*} \varepsilon_{k}+\varepsilon^{*}$

In equation (A1), $\alpha^{*}$ is the equilibrium liquid-vapor isotopic fractionation calculated from equations given by Horita and Wesolowski (1994):

$\left[\delta^{18} \mathrm{O}\right]: 1000 \ln \alpha^{*}=-7.685+6.7123\left(10^{3} / \mathrm{T}\right)-1.6664\left(10^{6} / \mathrm{T}^{2}\right)+0.35041\left(10^{9} / \mathrm{T}^{3}\right)$

$[\delta D]: 1000 \ln \alpha^{*}=1158.8\left(T^{3} / 10^{9}\right)-1620.1\left(T^{2} / 10^{6}\right)+794.84\left(T / 10^{3}\right)-161.04+$ $2.9992\left(10^{9} / T^{3}\right)$

In (A2) and (A3), T represents the interface temperature in Kelvin (K). The equilibrium $\left(\varepsilon^{\star}\right)$ and kinetic $\left(\varepsilon_{K}\right)$ separation factors between liquid and vapor phases are given by Gonfiantini (1986):

$\varepsilon^{*}=\alpha^{*}-1$

$\left[\delta^{18} \mathrm{O}\right]: \varepsilon_{\mathrm{K}}=0.0142(1-\mathrm{h})$ 
(A5)

$[\delta \mathrm{D}]: \varepsilon_{\mathrm{K}}=0.0125(1-\mathrm{h})$

Atmospheric vapor during the ice-free season $\left(\delta_{\mathrm{AS}}\right)$ is calculated assuming it is in isotopic equilibrium with local precipitation $\left(\delta_{\mathrm{PS}}\right)$ during the ice-free season:

$\delta_{\mathrm{AS}}=\left(\delta_{\mathrm{PS}}-\varepsilon^{*}\right) / \alpha^{*}$

The non-steady state isotope composition of a water body close to complete desiccation $\left(\delta^{\star}\right)$ was calculated from the equation given by Gonfiantini (1986):

$\delta^{*}=\left(h \delta_{A S}+\varepsilon_{K}+\varepsilon^{*} / \alpha^{*}\right) /\left(h-\varepsilon_{K}-\varepsilon^{*} / \alpha^{*}\right)$

Calculation of E/l ratios

Evaporation/inflow ratios (E/I) were calculated from the following equation as derived by Gibson and Edwards (2002) and others:

$\mathrm{E} / \mathrm{l}=\left(\delta_{\mathrm{I}}-\delta_{\mathrm{L}}\right) /\left(\delta_{\mathrm{E}}-\delta_{\mathrm{L}}\right)$

In (A9), $\delta_{\mathrm{L}}$ is the measured isotope composition of the surface lake water, $\delta_{\mathrm{I}}$ is the calculated lake-specific water source composition and $\delta_{\mathrm{E}}$ is the isotope composition of the associated evaporation flux, calculated by the formula: 
$\delta_{\mathrm{E}}=\left(\left(\delta_{\mathrm{L}}-\varepsilon^{*}\right) / \alpha^{*}-\mathrm{h} \delta_{\mathrm{AS}}-\varepsilon_{\mathrm{K}}\right) /\left(1-\mathrm{h}+\varepsilon_{\mathrm{K}}\right)($ Gonfiantini, 1986)

(A10)

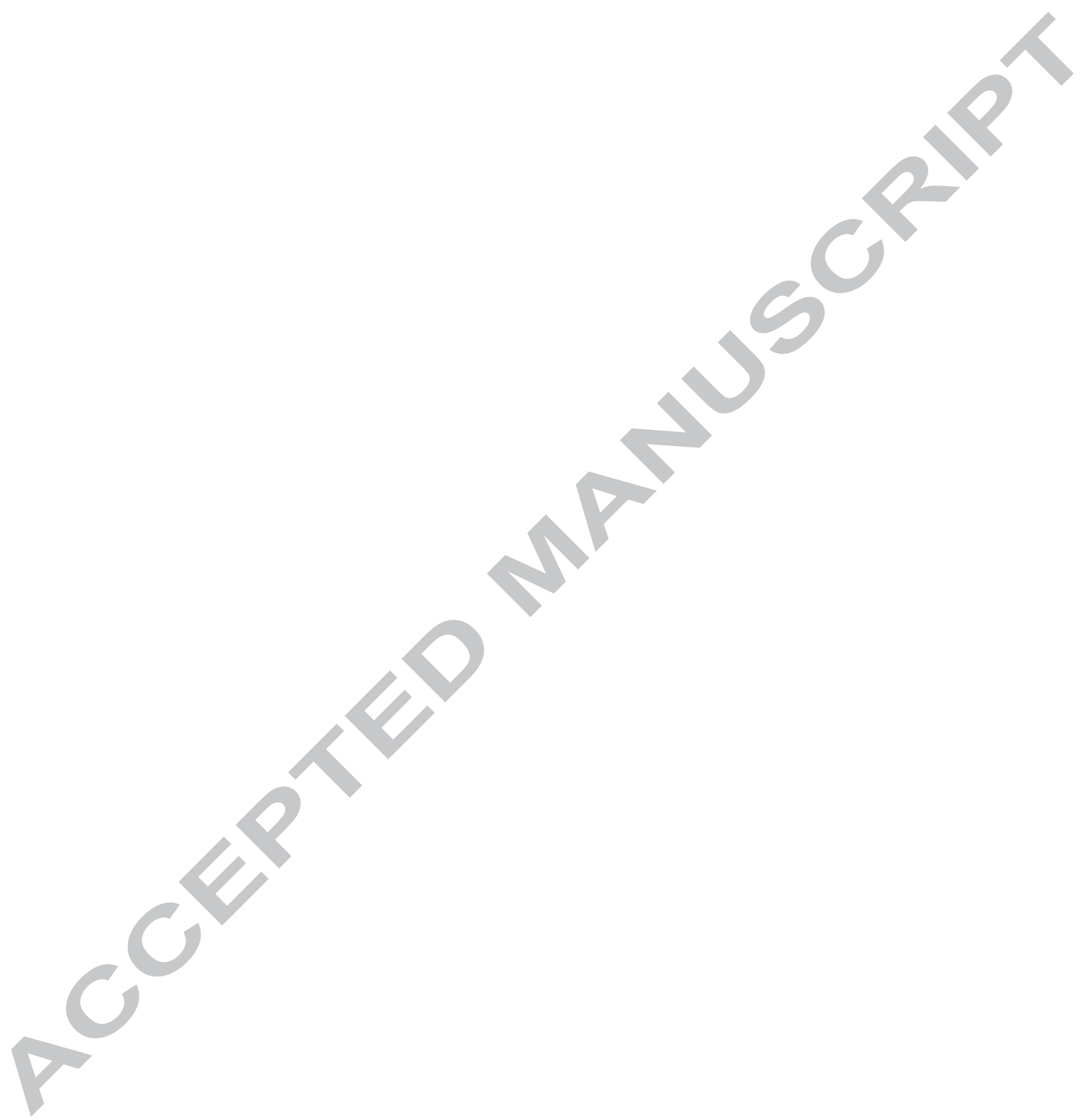




\section{SUPPLEMENTARY MATERIAL}

Table S1. Measured isotope composition of lake water $\left(\delta_{\mathrm{L}}\right)$, calculated lake-specific input water isotope composition $\left(\delta_{\mathrm{I}}\right)$, and evaporation-to-inflow (E/I) ratios, as well as permafrost and vegetation types specific to each site and individual lake. 
2012

\begin{tabular}{|c|c|c|c|c|c|c|c|c|c|c|c|c|c|c|c|c|}
\hline Lake & permafrost & Vegetation & $\delta_{\mathrm{L}}\left({ }^{18} \mathrm{O}\right)$ & $\delta_{\llcorner}(\mathrm{D})$ & $\delta_{L}\left({ }^{18} \mathrm{O}\right)$ & $\delta_{\mathrm{L}}(\mathrm{D})$ & $\delta_{1}\left({ }^{18} \mathrm{O}\right)$ & $\delta_{1}(\mathrm{D})$ & $E / I$ & $\delta_{L}\left({ }^{18} \mathrm{O}\right)$ & $\delta_{\llcorner}(\mathrm{D})$ & $\delta_{1}\left({ }^{18} \mathrm{O}\right)$ & $\delta_{1}(\mathrm{D})$ & $E / I$ & Lat $\left({ }^{\circ} \mathrm{N}\right)$ & Long $\left({ }^{\circ} \mathrm{W}\right)$ \\
\hline NAS H & discontinuous & Forest-Tundra & -11.9 & -87.0 & -13.1 & -99.1 & -14.1 & -103.1 & 0.04 & -11.8 & -97.3 & -15.5 & -113.8 & 0.18 & $56^{\circ} 36.518^{\prime}$ & $76^{\circ} 13.030^{\prime}$ \\
\hline NAS E & discontinuous & Forest-Tundra & & & -10.6 & -84.2 & -12.6 & -91.1 & 0.12 & -9.5 & -82.7 & -13.4 & -97.0 & 0.30 & $56^{\circ} 36.638^{\prime}$ & $76^{\circ} 12.854^{\prime}$ \\
\hline NAS C & discontinuous & Forest-Tundra & & & -11.7 & -89.9 & -13.1 & -94.9 & 0.07 & -11.6 & -91.3 & -13.6 & -98.6 & 0.10 & $56^{\circ} 55.429^{\prime}$ & $76^{\circ} 22.655^{\prime}$ \\
\hline NAS K & discontinuous & Forest-Tundra & & & -11.2 & -89.4 & -13.6 & -98.6 & 0.13 & -10.5 & -85.3 & -12.9 & -93.5 & 0.15 & $56^{\circ} 55.423^{\prime}$ & $76^{\circ} 22.750^{\prime}$ \\
\hline NAS F & discontinuous & Forest-Tundra & & & -12.9 & -99.3 & -14.5 & -105.7 & 0.06 & -11.8 & -89.5 & -12.8 & -92.7 & 0.05 & $56^{\circ} 55.360^{\prime}$ & $76^{\circ} 22.790^{\prime}$ \\
\hline NAS A & discontinuous & Forest-Tundra & -12.4 & -87.3 & -12.7 & -93.0 & -13.0 & -94.2 & 0.01 & -13.6 & -99.1 & -13.6 & -99.1 & 0.00 & $56^{\circ} 55.360^{\prime}$ & $76^{\circ} 22.790^{\prime}$ \\
\hline NAS D & discontinuous & Forest-Tundra & & & -13.8 & -104.2 & -14.8 & -108.3 & 0.04 & -13.1 & -97.4 & -13.7 & -99.8 & 0.03 & $56^{\circ} 55.450^{\prime}$ & $76^{\circ} 22.657^{\prime}$ \\
\hline NAS L & discontinuous & Forest-Tundra & & & -13.3 & -98.5 & -13.8 & -100.3 & 0.02 & -13.1 & -100.6 & -14.5 & -106.4 & 0.06 & $56^{\circ} 55.409^{\prime}$ & $76^{\circ} 22.792^{\prime}$ \\
\hline NAS G & discontinuous & Forest-Tundra & & & -13.8 & -102.7 & -14.3 & -104.7 & 0.02 & -13.5 & -99.1 & -13.7 & -99.7 & 0.01 & $56^{\circ} 55.432^{\prime}$ & $76^{\circ} 22.798^{\prime}$ \\
\hline NAS J & discontinuous & Forest-Tundra & -11.2 & -78.3 & -12.5 & -95.2 & -13.8 & -100.4 & 0.06 & -12.3 & -94.6 & -13.7 & -100.0 & 0.06 & $56^{\circ} 55.452^{\prime}$ & $76^{\circ} 22.636^{\prime}$ \\
\hline NAS B & discontinuous & Forest-Tundra & -12.2 & -86.9 & -13.5 & -97.4 & -13.4 & -96.9 & 0.00 & -13.3 & -97.1 & -13.4 & -97.5 & 0.00 & $56^{\circ} 55.429^{\prime}$ & $76^{\circ} 22.655^{\prime}$ \\
\hline NAS I & discontinuous & Forest-Tundra & & & -13.2 & -92.1 & -12.5 & -90.0 & -0.03 & -12.5 & -94.6 & -13.6 & -98.7 & 0.05 & $56^{\circ} 55.402^{\prime}$ & $76^{\circ} 22.753^{\prime}$ \\
\hline BGR B & discontinuous & Forest-Tundra & -11.1 & -84.4 & -12.7 & -100.4 & -15.2 & -111.4 & 0.11 & -12.3 & -96.7 & -14.4 & -105.0 & 0.09 & $56^{\circ} 36.652^{\prime}$ & $76^{\circ} 12.912^{\prime}$ \\
\hline BGR A & discontinuous & Forest-Tundra & -10.5 & -82.3 & -10.8 & -89.2 & -14.0 & -101.9 & 0.18 & -10.6 & -88.9 & -14.2 & -103.3 & 0.22 & $56^{\circ} 36.632^{\prime}$ & $76^{\circ} 12.937^{\prime}$ \\
\hline BGR F & discontinuous & Forest-Tundra & -12.3 & -87.9 & -14.4 & -107.7 & -15.1 & -110.6 & 0.02 & -13.4 & -103.9 & -15.2 & -111.4 & 0.07 & $56^{\circ} 36.609^{\prime}$ & $76^{\circ} 12.872^{\prime}$ \\
\hline BGR K & discontinuous & Forest-Tundra & & & -13.8 & -106.7 & -15.6 & -115.0 & 0.07 & -13.1 & -102.7 & -15.3 & -112.4 & 0.09 & $56^{\circ} 36.638^{\prime}$ & $76^{\circ} 12.854^{\prime}$ \\
\hline BGR I & discontinuous & Forest-Tundra & & & -11.6 & -92.4 & -14.0 & -102.2 & 0.12 & -11.1 & -92.7 & -14.8 & -108.4 & 0.20 & $56^{\circ} 36.503^{\prime}$ & $76^{\circ} 13.014^{\prime}$ \\
\hline BGR C & discontinuous & Forest-Tundra & & & -13.6 & -102.9 & -14.6 & -107.2 & 0.04 & -13.0 & -100.4 & -14.7 & -107.3 & 0.07 & $56^{\circ} 36.518^{\prime}$ & $76^{\circ} 13.030^{\prime}$ \\
\hline BGR J & discontinuous & Forest-Tundra & & & -13.8 & -105.7 & -15.2 & -111.5 & 0.05 & -13.5 & -103.4 & -14.9 & -109.6 & 0.06 & $56^{\circ} 36.613^{\prime}$ & $76^{\circ} 12.821^{\prime}$ \\
\hline BGR L & discontinuous & Forest-Tundra & & & -13.9 & -107.1 & -15.6 & -114.5 & 0.06 & -13.1 & -101.0 & -14.7 & -107.8 & 0.06 & $56^{\circ} 36.592^{\prime}$ & $76^{\circ} 12.728^{\prime}$ \\
\hline BGR G & discontinuous & Forest-Tundra & -10.2 & -80.7 & -10.9 & -87.9 & -13.4 & -97.5 & 0.14 & -11.2 & -91.3 & -14.1 & -103.0 & 0.16 & $56^{\circ} 36.557^{\prime}$ & $76^{\circ} 12.754^{\prime}$ \\
\hline BGR E & discontinuous & Forest-Tundra & & & -13.2 & -102.8 & -15.1 & -111.1 & 0.07 & -12.6 & -99.0 & -14.7 & -107.2 & 0.08 & $56^{\circ} 36.573^{\prime}$ & $76^{\circ} 12.773^{\prime}$ \\
\hline BGR Q & discontinuous & Forest-Tundra & & & -12.8 & -99.7 & -14.8 & -108.2 & 0.08 & -12.9 & -101.9 & -15.2 & -111.8 & 0.09 & $56^{\circ} 36.524^{\prime}$ & $76^{\circ} 13.040^{\prime}$ \\
\hline BGR M & discontinuous & Forest-Tundra & & & -11.4 & -92.1 & -14.2 & -103.6 & 0.15 & -10.6 & -92.1 & -15.6 & -114.8 & 0.30 & $56^{\circ} 36.512^{\prime}$ & $76^{\circ} 13.070^{\prime}$ \\
\hline BGR EYE & discontinuous & Forest-Tundra & & & -12.4 & -96.6 & -14.2 & -103.8 & 0.08 & -12.1 & -94.2 & -13.9 & -101.3 & 0.09 & $56^{\circ} 36.503^{\prime}$ & $76^{\circ} 13.071^{\prime}$ \\
\hline BGR N & discontinuous & Forest-Tundra & & & -11.8 & -96.3 & -15.1 & -110.5 & 0.15 & -9.1 & -84.2 & -15.2 & -111.2 & 0.52 & $56^{\circ} 36.483^{\prime}$ & $76^{\circ} 13.003^{\prime}$ \\
\hline BGR P & discontinuous & Forest-Tundra & & & -12.2 & -95.5 & -14.2 & -103.3 & 0.09 & -10.3 & -88.3 & -14.5 & -106.1 & 0.27 & $56^{\circ} 36.481^{\prime}$ & $76^{\circ} 12.962^{\prime}$ \\
\hline $\begin{array}{l}\text { BGR } \\
\text { HELI. }\end{array}$ & discontinuous & Forest-Tundra & & & & & -13.8 & -100.3 & 0.27 & & & & & & $56^{\circ} 36.483^{\prime}$ & $76^{\circ} 13.003^{\prime}$ \\
\hline BGR O & discontinuous & Forest-Tundra & & & -10 & -89.0 & -13.8 & -100.2 & 0.16 & & & & & & $56^{\circ} 36.483^{\prime}$ & $76^{\circ} 13.003^{\prime}$ \\
\hline KWK 6 & sporadic & Boreal Forest & -8.0 & -72.5 & -8.5 & -79.7 & -14.2 & -103.9 & 0.71 & -9.1 & -80.7 & -13.0 & -94.2 & 0.33 & $55^{\circ} 19.853^{\prime}$ & $77^{\circ} 30.166^{\prime}$ \\
\hline
\end{tabular}




\begin{tabular}{|c|c|c|c|c|c|c|c|c|c|c|c|c|c|c|c|c|}
\hline KWK 3 & sporadic & Boreal Forest & & & -11.6 & -97.6 & -16.2 & -119.5 & 0.23 & -12.0 & -92.6 & -13.4 & -97.6 & 0.07 & $55^{\circ} 29.836^{\prime}$ & $77^{\circ} 30.183^{\prime}$ \\
\hline KWK 8 & sporadic & Boreal Forest & & & -11.1 & -92.7 & -15.0 & -110.2 & 0.22 & -12.0 & -92.6 & -13.5 & -97.7 & 0.07 & $55^{\circ} 19.878^{\prime}$ & $77^{\circ} 30.175^{\prime}$ \\
\hline KWK 4 & sporadic & Boreal Forest & & & -9.7 & -86.7 & -15.2 & -111.5 & 0.43 & -10.7 & -88.8 & -13.8 & -100.3 & 0.18 & $55^{\circ} 19.904^{\prime}$ & $77^{\circ} 30.161^{\prime}$ \\
\hline KWK 25 & sporadic & Boreal Forest & & & -10.7 & -88.2 & -13.6 & -99.1 & 0.18 & -11.6 & -90.4 & -13.3 & -96.5 & 0.09 & $55^{\circ} 19.923^{\prime}$ & $77^{\circ} 30.149^{\prime}$ \\
\hline KWK 17 & sporadic & Boreal Forest & & & -10.9 & -89.2 & -13.8 & -100.1 & 0.17 & & & & & & & \\
\hline KWK 28 & sporadic & Boreal Forest & & & -10.1 & -86.8 & -14.3 & -104.1 & 0.30 & -11.2 & -89.3 & -13.3 & -96.7 & 0.11 & $55^{\circ} 19.937^{\prime}$ & $77^{\circ} 30.110^{\prime}$ \\
\hline KWK 7 & sporadic & Boreal Forest & & & -10.4 & -86.4 & -13.5 & -98.4 & 0.21 & -10.7 & -89.2 & -14.0 & -102.2 & 0.19 & $55^{\circ} 19.937^{\prime}$ & $77^{\circ} 30.077^{\prime}$ \\
\hline KWK 30 & sporadic & Boreal Forest & & & -10.8 & -90.5 & -14.5 & -105.9 & 0.22 & -11.3 & -90.5 & -13.6 & -98.9 & 0.12 & $55^{\circ} 19.919^{\prime}$ & $77^{\circ} 30.092^{\prime}$ \\
\hline KWK 18 & sporadic & Boreal Forest & & & -7.8 & -75.4 & -13.0 & -94.1 & 0.96 & -10.4 & -85.8 & -13.2 & -95.6 & 0.17 & $55^{\circ} 19.972^{\prime}$ & $77^{\circ} 29.975^{\prime}$ \\
\hline KWK 9 & sporadic & Boreal Forest & & & -9.0 & -82.5 & -14.7 & -107.5 & 0.58 & -8.7 & -81.6 & -14.4 & -105.4 & 0.55 & $55^{\circ} 19.794^{\prime}$ & $77^{\circ} 30.184^{\prime}$ \\
\hline KWK 31 & sporadic & Boreal Forest & & & -10.5 & -89.6 & -14.7 & -107.9 & 0.27 & -9.6 & -84.5 & -13.8 & -100.7 & 0.31 & $55^{\circ} 19.824^{\prime}$ & $77^{\circ} 30.211^{\prime}$ \\
\hline KWK 16 & sporadic & Boreal Forest & & & -10.5 & -87.9 & -13.9 & -101.3 & 0.22 & -11.4 & -87.4 & -12.6 & -91.2 & 0.06 & $55^{\circ} 19.814^{\prime}$ & $77^{\circ} 30.245^{\prime}$ \\
\hline KWK 11 & sporadic & Boreal Forest & & & -11.6 & -94.2 & -14.5 & -106.3 & 0.15 & -11.5 & -87.8 & -12.7 & -91.5 & 0.06 & $55^{\circ} 19.827^{\prime}$ & $77^{\circ} 30.158^{\prime}$ \\
\hline KWK 12 & sporadic & Boreal Forest & -10.5 & -79.7 & -11.9 & -95.3 & -14.6 & -106.6 & 0.13 & -11.6 & -92.1 & -13.8 & -100.3 & 0.11 & $55^{\circ} 19.815^{\prime}$ & $77^{\circ} 30.137^{\prime}$ \\
\hline KWK 5 & sporadic & Boreal Forest & & & -11.8 & -95.1 & -14.6 & -106.4 & 0.13 & -12.1 & -93.8 & -13.7 & -99.5 & 0.07 & $55^{\circ} 19.794^{\prime}$ & $77^{\circ} 30.184^{\prime}$ \\
\hline KWK 19 & sporadic & Boreal Forest & & & -10.1 & -88.0 & -14.9 & -109.3 & 0.35 & -11.4 & -90.0 & -13.4 & -97.0 & 0.10 & $55^{\circ} 19.793^{\prime}$ & $77^{\circ} 30.184^{\prime}$ \\
\hline KWK 2 & sporadic & Boreal Forest & & & -11.7 & -92.6 & -13.9 & -100.8 & 0.11 & -11.8 & -94.7 & -14.3 & -104.3 & 0.12 & $55^{\circ} 19.801^{\prime}$ & $77^{\circ} 30.274^{\prime}$ \\
\hline KWK 10 & sporadic & Boreal Forest & & & -10.0 & -86.6 & -14.2 & -104.0 & 0.30 & -9.4 & -84.4 & -14.4 & -104.9 & 0.39 & $55^{\circ} 19.782^{\prime}$ & $77^{\circ} 30.266^{\prime}$ \\
\hline KWK 26 & sporadic & Boreal Forest & & & -11.9 & -97.1 & -15.2 & -111.9 & 0.16 & -11.0 & -88.9 & -13.5 & -97.7 & 0.13 & $55^{\circ} 19.942^{\prime}$ & $77^{\circ} 30.141^{\prime}$ \\
\hline KWK 14 & sporadic & Boreal Forest & & & -10.1 & -87.1 & -14.4 & -105.6 & 0.31 & -8.8 & -81.7 & -14.1 & -102.8 & 0.48 & $55^{\circ} 19.942^{\prime}$ & $77^{\circ} 30.159^{\prime}$ \\
\hline KWK 23 & sporadic & Boreal Forest & -9.5 & -79.9 & -10.9 & -88.8 & -13.6 & -99.1 & 0.16 & -8.8 & -85.5 & -17.5 & -130.0 & 0.80 & $55^{\circ} 19.980^{\prime}$ & $77^{\circ} 30.120^{\prime}$ \\
\hline KWK 27 & sporadic & Boreal Forest & & & -11.9 & -96.2 & -14.8 & -108.4 & 0.14 & -11.1 & -88.9 & -13.3 & -96.4 & 0.12 & $55^{\circ} 19.958^{\prime}$ & $77^{\circ} 30.116^{\prime}$ \\
\hline KWK 15 & sporadic & Boreal Forest & & & -10.3 & -90.3 & -15.6 & -114.9 & 0.35 & -9.2 & -84.7 & -15.0 & -109.8 & 0.47 & $55^{\circ} 19.976^{\prime}$ & $77^{\circ} 30.126^{\prime}$ \\
\hline KWK 20 & sporadic & Boreal Forest & & & -11.0 & -92.8 & -15.1 & -110.8 & 0.23 & -10.8 & -90.3 & -14.2 & -103.7 & 0.19 & $55^{\circ} 19.919^{\prime}$ & $77^{\circ} 30.132^{\prime}$ \\
\hline KWK 32 & sporadic & Boreal Forest & & & -11.7 & -93.8 & -14.2 & -104.0 & 0.13 & -12.2 & -93.2 & -13.4 & -97.6 & 0.06 & $55^{\circ} 19.920^{\prime}$ & $77^{\circ} 30.180^{\prime}$ \\
\hline KWK 21 & sporadic & Boreal Forest & & & -11.5 & -93.2 & -14.4 & -104.9 & 0.15 & -11.5 & -90.5 & -13.4 & -97.4 & 0.10 & $55^{\circ} 19.907^{\prime}$ & $77^{\circ} 30.205^{\prime}$ \\
\hline KWK 36 & sporadic & Boreal Forest & & & -11.5 & -93.0 & -14.3 & -104.4 & 0.14 & -12.2 & -90.9 & -12.9 & -93.0 & 0.03 & $55^{\circ} 19.976^{\prime}$ & $77^{\circ} 30.081^{\prime}$ \\
\hline KWK 37 & sporadic & Boreal Forest & & & -11.7 & -93.3 & -14.2 & -103.5 & 0.13 & -12.0 & -93.2 & -13.6 & -99.2 & 0.08 & $55^{\circ} 19.920^{\prime}$ & $77^{\circ} 30.000^{\prime}$ \\
\hline KWK 24 & sporadic & Boreal Forest & & & -11.9 & & -14.9 & -109.6 & 0.14 & -10.9 & -90.7 & -14.3 & -104.1 & 0.19 & $55^{\circ} 19.920^{\prime}$ & $77^{\circ} 30.060^{\prime}$ \\
\hline KWK 33 & sporadic & Boreal Forest & & & -11.2 & -92.9 & -14.8 & -108.4 & 0.20 & -10.9 & -86.2 & -12.8 & -92.1 & 0.10 & $55^{\circ} 19.900^{\prime}$ & $77^{\circ} 30.099^{\prime}$ \\
\hline KWK 22 & sporadic & Boreal Forest & & & -11.3 & -92.3 & -14.4 & -105.3 & 0.17 & -11.9 & -89.5 & -12.8 & -92.4 & 0.04 & $55^{\circ} 19.860^{\prime}$ & $77^{\circ} 30.120^{\prime}$ \\
\hline KWK 1 & sporadic & Boreal Forest & -10.2 & & -12.3 & -98.5 & -15.1 & -110.8 & 0.13 & -12.9 & -99.0 & -14.3 & -104.2 & 0.05 & $55^{\circ} 19.960^{\prime}$ & $77^{\circ} 30.151^{\prime}$ \\
\hline KWK 29 & sporadic & Boreal Forest & & & -9.0 & -82.1 & -14.2 & -103.5 & 0.51 & -11.0 & -89.1 & -13.5 & -98.0 & 0.13 & $55^{\circ} 20.012^{\prime}$ & $77^{\circ} 30.100^{\prime}$ \\
\hline KWK38/39 & sporadic & Boreal Forest & & & -9.3 & -81.2 & -13.0 & -94.2 & 0.34 & & & & & & $55^{\circ} 19.980^{\prime}$ & $77^{\circ} 29.971^{\prime}$ \\
\hline SAS Y & sporadic & Boreal Forest & & & -10.0 & -84.6 & -13.3 & -96.4 & 0.23 & -12.0 & -91.2 & -13.1 & -95.1 & 0.05 & $55^{\circ} 13.228^{\prime}$ & $77^{\circ} 42.444^{\prime}$ \\
\hline SAS $1 E$ & sporadic & Boreal Forest & -11.4 & & -12.5 & -98.6 & -14.7 & -108.0 & 0.10 & -12.5 & -94.4 & -13.5 & -97.9 & 0.04 & $55^{\circ} 13.228^{\prime}$ & $77^{\circ} 42.444^{\prime}$ \\
\hline SAS 2B & sporadic & Boreal Forest & & & -12.1 & -92.5 & -13.4 & -97.3 & 0.06 & -13.4 & -97.7 & -13.5 & -97.9 & 0.00 & $55^{\circ} 13.608^{\prime}$ & $77^{\circ} 41.735^{\prime}$ \\
\hline
\end{tabular}




$\begin{array}{ll}\text { SAS 2D } & \text { sporadic } \\ \text { SAS 2G } & \text { sporadic } \\ \text { SAS 2C } & \text { sporadic } \\ \text { SAS 1F } & \text { sporadic } \\ \text { SAS 1D } & \text { sporadic } \\ \text { SAS X } & \text { sporadic } \\ \text { SAS Z } & \text { sporadic } \\ \text { SAS 1H } & \text { sporadic } \\ \text { SAS 1C } & \text { sporadic } \\ \text { SAS 2F } & \text { sporadic } \\ \text { SAS 2E } & \text { sporadic } \\ \text { SAS 1B } & \text { sporadic } \\ \text { SAS 1K } & \text { sporadic } \\ \text { SAS 2A } & \text { sporadic } \\ \text { SAS 1J } & \text { sporadic } \\ \text { SAS 1L } & \text { sporadic } \\ \text { SAS 1G } & \text { sporadic } \\ \text { SAS 2H } & \text { sporadic } \\ \text { SAS 1A } & \text { sporadic }\end{array}$

$\begin{array}{llll}\text { Boreal Forest } & & & -12.2 \\ \text { Boreal Forest } & & & -12.3 \\ \text { Boreal Forest } & & & -11.5 \\ \text { Boreal Forest } & -10.6 & -85.7 & -12.9 \\ \text { Boreal Forest } & & & -11.9 \\ \text { Boreal Forest } & & & -9.7 \\ \text { Boreal Forest } & & & -11.2 \\ \text { Boreal Forest } & & & -11.9 \\ \text { Boreal Forest } & & & -12.5 \\ \text { Boreal Forest } & & & -12.7 \\ \text { Boreal Forest } & & & -11.7 \\ \text { Boreal Forest } & & & -13.4 \\ \text { Boreal Forest } & & -12.6 \\ \text { Boreal Forest } & -11.6 & -90.8 & -12.3 \\ \text { Boreal Forest } & & & -12.3 \\ \text { Boreal Forest } & & & -12.3 \\ \text { Boreal Forest } & & & -13.1 \\ \text { Boreal Forest } & & & -11.9 \\ \text { Boreal Forest } & -11.2 & -89.0 & -12.4\end{array}$

$\begin{array}{ll}-90.6 & -12.8 \\ -95.4 & -14.0 \\ -90.5 & -13.5 \\ -99.3 & -14.4 \\ -94.8 & -14.3 \\ -80.9 & -12.4 \\ -86.6 & -12.7 \\ -94.7 & -14.3 \\ -100.1 & -15.4 \\ -96.8 & -13.9 \\ -92.7 & -13.9 \\ -99.7 & -14.0 \\ -102.1 & -15.9 \\ -93.7 & -13.6 \\ -99.9 & -15.6 \\ -101.3 & -16.3 \\ -100.2 & -14.5 \\ -96.2 & -14.8 \\ -99.0 & -15.2\end{array}$

-92.8
-102.0
-97.6
-105.2
-104.2
-88.9
-91.4
-104.4
-113.1
-101.3
-101.6
-101.9
-117.6
-98.4
-114.4
-120.4
-106.2
-108.6
-111.2

0.03
0.08
0.10
0.06
0.11
0.21
0.08
0.11
0.13
0.05
0.11
0.02
0.14
0.06
0.14
0.18
0.06
0.14
0.12

\section{$-13.3$}

$-13.3$

$-96.4$

$-96.4$

$-13.3$

$-11.8$

$-91.3$

$-13.2$

$-12.7$

$-8$

$\begin{array}{ll}-13.3 & -96.5 \\ -13.5 & -98.4\end{array}$

$\begin{array}{lll}-95.4 & -13.5 & -98.4\end{array}$

$-12.8$

$-97.8$

$-87.1$

$-11.9$

$-90.8$

$-14.1 \quad-102.6$

$-12.8 \quad-92.6$

$-12.0$

$-92.4$

$-13.1-94.8$

$-13.4 \quad-97.2$

$-12.4$

$\begin{array}{lll}-96.6 & -14.2 & -103.4\end{array}$

$-12.4$

$-12.2$

$\begin{array}{lll}-94.2 & -13.5 & -97.8\end{array}$

$\begin{array}{lll}-93.6 & -13.6 & -98.6\end{array}$

$-12.2$

$\begin{array}{lll}-95.3 & -14.0 & -102.3\end{array}$

$\begin{array}{llll}-11.1 & -91.1 & -14.1 & -102.9\end{array}$

$\begin{array}{llll}-12.9 & -98.0 & -14.1 & -102.6\end{array}$

$\begin{array}{llll}-12.5 & -94.9 & -13.6 & -99.0\end{array}$

$\begin{array}{llll}-12.6 & -93.8 & -13.2 & -96.0\end{array}$

$\begin{array}{lll}-93.8 & -13.2 & -96.0 \\ -98.0 & -13.6 & -98.8\end{array}$

-13.4
-13.5
-13.0

$-97.1$

$-13.3$

$-13.0$

$-97.4$
0.00

0.00

0.07

0.04

0.05

0.09

0.06

0.06

0.08

0.04

0.06

0.08

0.16

0.05

0.05

0.03

0.01

0.00

0.03 $55^{\circ} 13.595^{\prime}$ $55^{\circ} 13.589^{\prime}$ $55^{\circ} 13.610^{\prime}$ $55^{\circ} 13.599^{\prime}$

$55^{\circ} 13.621^{\prime}$

$55^{\circ} 13.380^{\prime}$

$55^{\circ} 13.382^{\prime}$

$55^{\circ} 13.387^{\prime}$

$55^{\circ} 13.591^{\prime}$

$55^{\circ} 13.600^{\prime}$

$55^{\circ} 13.608^{\prime}$

$55^{\circ} 13.595^{\prime}$

$55^{\circ} 13.589^{\prime}$

$55^{\circ} 13.610^{\prime}$

55⒔599'

$55^{\circ} 13.621^{\prime}$

$55^{\circ} 13.342^{\prime}$

$55^{\circ} 13.342^{\prime}$

$55^{\circ} 13.342^{\prime}$ $77^{\circ} 41.857^{\prime}$ $77^{\circ} 41.879^{\prime}$ $77^{\circ} 41.854^{\prime}$ $77^{\circ} 41.896^{\prime}$ $77^{\circ} 41.760^{\prime}$ $77^{\circ} 42.360^{\prime}$ $77^{\circ} 42.360^{\prime}$ $77^{\circ} 42.360^{\prime}$ $77^{\circ} 41.815^{\prime}$ $77^{\circ} 41.806^{\prime}$ $77^{\circ} 41.735^{\prime}$ $77^{\circ} 41.857^{\prime}$ $77^{\circ} 41.879^{\prime}$ $77^{\circ} 41.854^{\prime}$ $77^{\circ} 41.896^{\prime}$ $77^{\circ} 41.760^{\prime}$ $77^{\circ} 42.348^{\prime}$ $77^{\circ} 42.348^{\prime}$ $77^{\circ} 42.348^{\prime}$ 


\section{REFERENCES}

ACIA, 2004. Impact of a Warming Arctic: Arctic Climate Impact Assessment, Cambridge University Press.

Agafonov, L., Strunk, H., Nuber, T., 2004. Thermokarst dynamics in Western Siberia: Insights from dendrochronological research. Palaeogeogr. Palaeoclimatol. Palaeoecol. 209, 183196. doi:10.1016/j.palaeo.2004.02.024

Allard, M., K.-Seguin, M., 1987. Le pergélisol au Québec nordique : bilan et perspectives. Géographie Phys. Quat. 41, 141. doi:10.7202/032671ar

Anderson, L., Birks, J., Rover, J., Guldager, N., 2013. Controls on recent Alaskan lake changes identified from water isotopes and remote sensing. Geophys. Res. Lett. 40, 3413-3418. doi:10.1002/grl.50672

Bhiry, N., Robert, É.C., 2006. Reconstruction of changes in vegetation and trophic conditions of a palsa in a permafrost peatland, subarctic Québec, Canada. Ecoscience 13, 56-65. doi:10.2980/1195-6860(2006)13[56:ROCIVA]2.0.CO;2

Bouchard, F., Francus, P., Pienitz, R., Laurion, I., 2011. Sedimentology and geochemistry of thermokarst ponds in discontinuous permafrost, subarctic Quebec, Canada. J. Geophys. Res. Biogeosciences 116, 1-14. doi:10.1029/2011JG001675

Bouchard, F., Francus, P., Pienitz, R., Laurion, I., Feyte, S., 2014. Subarctic thermokarst ponds: investigating recent landscape evolution and sediment dynamics in thawed permafrost of northern Québec (Canada). Arctic, Antarct. Alp. Res. 46, 251-271. doi:10.1657/1938-424646.1.251

Bouchard, F., Pienitz, R., Ortiz, J.D., Francus, P., Laurion, I., 2013. Palaeolimnological conditions inferred from fossil diatom assemblages and derivative spectral properties of sediments in thermokarst ponds of subarctic Quebec, Canada. Boreas 42, 575-595. doi:10.1111/bor.12000

Brown, R., Lemay, M., Allard, M., Barrand, N.E., Barrette, C., Bégin, Y., Bell, T., Bernier, M., 
Bleau, S., Chaumont, D., Dibike, Y., Frigon, A., Leblanc, P., Paquin, D., Sharp, M.J., Way, R., 2012. Climate variability and change in the Canadian Eastern Subarctic IRIS region (Nunavut and Nunatsiavut). Pages 57-113 dans Allard, M., Lemay, M. (Éditeurs). Nunavik and Nunatsiavut: From science to policy. An Integrated Regional Impact Study (IRIS) of climate change and modernization. ArcticNet Inc. Québec, Québec, Canada.

Calmels, F., Allard, M., Delisle, G., 2008. Development and decay of a lithalsa in Northern Québec : A geomorphological history 97, 287-299. doi:10.1016/j.geomorph.2007.08.013

Comte, J., Monier, A., Crevecoeur, S., Lovejoy, C., Vincent, W.F., 2015. Microbial biogeography of permafrost thaw ponds across the changing northern landscape. Ecography (Cop.). n/an/a. doi:10.1111/ecog.01667

Craig, H., Gordon, L.I., 1965. Deuterium and oxygen 18 variations in the ocean and the marine atmosphere. In: Tongiorgi, E. (Ed.), Stable Isotope in Oceanographic Studies and Paleotemperatures. Laboratorio di Geologia Nucleare, Pisa, Italy, pp. 570 9-130. Crevecoeur, S., Vincent, W.F., Comte, J., Lovejoy, C., 2015. Bacterial community structure across environmental gradients in permafrost thaw ponds: methanotroph-rich ecosystems. Front. Microbiol. 6, 1-15. doi:10.3389/fmicb.2015.00192

Dansgaard, W., 1964. Stable isotopes in precipitation. Tellus A. doi:10.3402/tellusa.v16i4.8993

Deshpande, B.N., Maclntyre, S., Matveev, A., Vincent, W.F., 2015. Oxygen dynamics in permafrost thaw lakes: Anaerobic bioreactors in the Canadian subarctic. Limnol. Oceanogr. 60, 1656-1670. doi:10.1002/Ino.10126

Environment Canada, 2015. National Climate Data and Information Archive. <httpp://www.weather.gc.ca/climateData>.

Epstein, S., Mayeda, T., 1953. Variation of O-18 content of waters from natural sources. Geochemica Cosmochim. Acta 4, 213-224. doi:10.1016/0016-7037(53)90051-9 Gonfiantini, R., 1986. Environmental isotopes in lake studies. In: Fritz, P., Fontes, J.- C. (Eds.), Handbook of Environmental Isotope Geochemistry, The Terrestrial Environment, vol. 
2. 26 Elsevier, New York, pp. 113-168.

Horita, J., Wesolowski, D., 1994. Liquid-vapour fractionation of oxygen and hydrogen isotopes of water from the freezing to the critical temperature. Geochimica et Cosmochimica Acta 58, 3425-3437.

Gibson, J.J., Edwards, T.W.D., 2002. Regional water balance trends and evaporative transpiration partitioning from a stable isotope survey of lakes in northern Canada. Global Biogeochemical Cycles 16. doi:10.1029/2001GB001839.

Gibson, J.J., Reid, R., 2014. Water balance along a chain of tundra lakes: A 20 -year isotopic perspective. J. Hydrol. 519, 2148-2164. doi:10.1016/j.jhydrol.2014.10.011

Gibson, J.J., Birks, S.J., Yi, Y., Vitt, D.H., 2015. Runoff to boreal lakes linked to land cover, watershed morphology and permafrost thaw: A 9-year isotope mass balance assessment. Hydrol. Process. 3861, 3848-3861. doi:10.1002/hyp.10502

Gibson, J.J., Birks, S.J., Yi, Y., 2016a. Higher tritium concentrations measured in permafrost thaw lakes in northern Alberta. Hydrol. Process. 30, 245-249. doi:10.1002/hyp.10599 Gibson, J.J., Birks, S.J., Yi, Y., 2016b. Stable isotope mass balance of lakes: A contemporary perspective. Quat. Sci. Rev. 131, 316-328. doi:10.1016/j.quascirev.2015.04.013

Gonfiantini, R., 1986. Environmental isotopes in lake studies. In: Fritz, P., Fontes, J.- C. (Eds.), Handbook of Environmental Isotope Geochemistry, The Terrestrial Environment, vol. 2. Elsevier, New York, pp. 113-168.

Jones, M.D., Cuthbert, M.O., Leng, M.J., McGowan, S., Mariethoz, G., Arrowsmith, C., Sloane, H.J., Humphrey, K.K., Cross, I., 2016. Comparisons of observed and modelled lake $\delta^{18} \underline{O}$ variability. Quat. Sci. Rev. 131, 329-340. doi:10.1016/j.quascirev.2015.09.012

Laurion, I., Vincent, W.F., Maclntyre, S., Retamal, L., Dupont, C., Francus, P., Pienitz, R., 2010. Variability in greenhouse gas emissions from permafrost thaw ponds. Limnol. Oceanogr. 55, 115-133. doi:10.4319/lo.2010.55.1.0115

Leng, M.J., Anderson, J.N., 2003. Isotopic variation in modern lake waters from 
western Greenland. The Holocene 13, 605-611. doi: 10.1191/0959683603hl620rr

MacDonald, L.A., Turner, K.W., Balasubramaniam, A.M., Wolfe, B.B., Hall, R.I., Sweetman, J.N., 2012. Tracking hydrological responses of a thermokarst lake in the Old Crow Flats (Yukon Territory, Canada) to recent climate variability using aerial photographs and paleolimnological methods. Hydrol. Process. 26, 117-129. doi:10.1002/hyp.8116 MacDonald, L.A., Wolfe, B.B, Turner, K.W, Anderson, L., Arp, C.D, Birks, S.J., Bouchard, F.,

Edwards, T.W.D, Farquharson, N., Hall R.I., McDonald, I., Narancic, B., Ouimet, C.,

Pienitz, R., Tondu, J. and White, H., accepted. A synthesis of thermokarst lake water balance in high-latitude regions of North America from isotope tracers. Arctic Science

Matveev, A., Laurion, I., Deshpande, B.N., Bhiry, N., Vincent, W.F., 2016. High methane emissions from thermokarst lakes in subarctic peatlands. Limnol. Oceanogr. doi:10.1002//no.10311

Meyer, H., Sch"onicke, L., Wand, U., Hubberten, H. W., and Friedrichsen, H., 2000. Isotope studies of hydrogen and oxygen in ground ice - experiences with the equilibration technique. Isot. Environm. Heal. S., 36, 133-149. doi:10.1080/10256010008032939

Morrison, J., Brockwell, T., Merren, T., Fourel, F., Phillips, a M., 2001. On-line high precision stable hydrogen isotopic analyses on nanoliter water samples. Anal. Chem. 73, 3570-3575.

Payette, S., Delwaide, A., Caccianiga, M., Beauchemin, M., 2004. Accelerated thawing of subarctic peatland permafrost over the last 50 years. Geophys. Res. Lett. 31,1-4. doi:10.1029/2004GL020358

Pienitz, R., Lortie, G., Allard, M., 1991. Isolation of lacustrine basins and marine regression in the Kuujjuaq area, northern Québec, as inferred from diatom analysis. Géographie Phys. Quat. 45, 155. doi:10.7202/032858ar

Pienitz, R., Doran, P.T., Lamoureux, S., 2008. Origin and geomorphology of lakes in the polar regions. In: Vincent, W.F. \& Laybourn-Parry, J. (eds), Polar lakes and rivers - Limnology of Arctic and Antarctic aquatic ecosystems, pp. 25-41. 
Pienitz, R., Bouchard, F., Narancic, B., Vincent, W.F., Sarrazin, D. 2016. Seasonal ice cover and catchment changes at northern thermokarst ponds in Nunavik: Observations from automated time-lapse cameras, v. 1.0 (2014-2015). Nordicana D24. doi: 10.5885/45418ADAF6A8064C702444B.

Prairie, Y., Breton, J., Vallières, C., Laurion, I., 2009. Limnological properties of permafrost thaw ponds in northeastern Canada. Can. J. Fish. Aquat. Sci. 66, 1635-1648. doi:10.1139/F09108

Przytulska, A., Comte, J., Crevecoeur, S., Lovejoy, C., Laurion, I., Vincent, W.F., 2015.

Phototrophic pigment diversity and picophytoplankton abundance in permafrost thaw lakes, Biogeosciences Discussions. doi:10.5194/bgd-12-12121-2015

Rozanski, K, Araguas-Araguas, L, Gonfiantini, R., 1993. Isotope patterns in modern global precipitation. Science (80-.). 258, 981-985.

Saulnier-Talbot, É., Leng, M.J., Pienitz, R., 2007. Recent climate and stable isotopes in modern surface waters of northernmost Ungava Peninsula, Canada. Can. J. Earth Sci. 44, 171180. doi:10.1139/e06-089

Steinman, B.A., Abbott, M.B., Nelson, D.B., Stansell, N.D., Finney, B.P., Bain, D.J., Rosenmeier, M.F., 2013. Isotopic and hydrologic responses of small, closed lakes to climate variability: Comparison of measured and modeled lake level and sediment core oxygen isotope records. Geochim. Cosmochim. Acta 105, 455-471. doi:10.1016/j.gca.2012.11.026

Thornthwaite, C.,1948. An approach toward a rational classification of climate. The Geographical Review, 38, 1-94.

Tondu, J.M.E., Turner, K.W., Wolfe, B.B., Hall, R.I., Edwards, T.W.D., McDonald, I., 2013. Using water isotope tracers to develop the hydrological component of a long-term aquatic ecosystem monitoring program for a northern lake-rich landscape. Arctic, Antarct. Alp. Res. 45, 594-614. doi:10.1657/1938-4246-45.4.594

Turner, K.W., Wolfe, B.B., Edwards, T.W.D., 2010. Characterizing the role of hydrological 
processes on lake water balances in the Old Crow Flats, Yukon Territory, Canada, using water isotope tracers. J. Hydrol. 386, 103-117. doi:10.1016/j.jhydrol.2010.03.012

Turner, K.W., Wolfe, B.B., Edwards, T.W.D., Lantz, T.C., Hall, R.I., Larocque, G., 2014. Controls on water balance of shallow thermokarst lakes and their relations with catchment characteristics: A multi-year, landscape-scale assessment based on water isotope tracers and remote sensing in Old Crow Flats, Yukon (Canada). Glob. Chang. Biol. 1585-1603. doi:10.1111/gcb.12465

Watanabe, S., Laurion, I., Chokmani, K., Pienitz, R., Vincent, W.F., 2011. Optical diversity of thaw ponds in discontinuous permafrost: A model system for water color analysis. J. Geophys. Res. Biogeosciences 116, 1-17. doi:10.1029/2010JG001380

Wik, M., Varner, R.K., Anthony, K.W., Maclntyre, S., Bastviken, D., 2016. Climate-sensitive northern lakes and ponds are critical components of methane release. Nat. Geosci. advance on. doi:10.1038/ngeo2578

Wolfe, B.B., Light, E.M., Macrae, M.L., Hall, R.I., Eichel, K., Jasechko, S., White, J., Fishback, L., Edwards, T.W.D., 2011. Divergent hydrological responses to 20th century climate change in shallow tundra ponds, western Hudson Bay Lowlands. Geophys. Res. Lett. 38, 1-6. doi:10.1029/2011GL049766

Yi, Y., Brock, B.E., Falcone, M.D., Wolfe, B.B., Edwards, T.W.D., 2008. A coupled isotope tracer method to characterize input water to lakes. J. Hydrol. 350, 1-13.

doi:10.1016/j.jhydrol.2007.11.008 


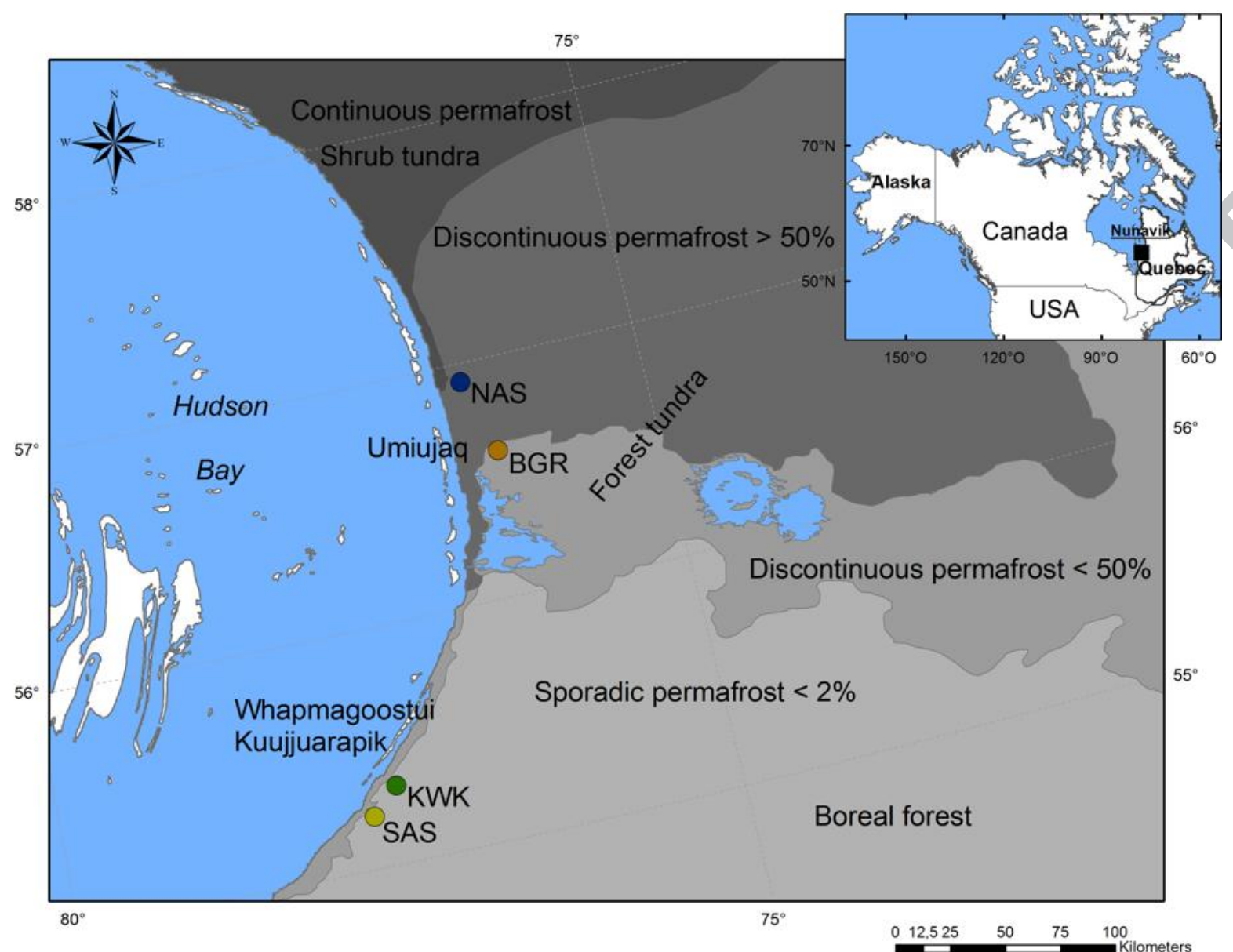

Fig. 1 Geographic location of the Nunavik sampling sites. Permafrost distribution was taken from Allard and Lemay (2012). 


\section{ACCEPTED MANUSCRIPT}

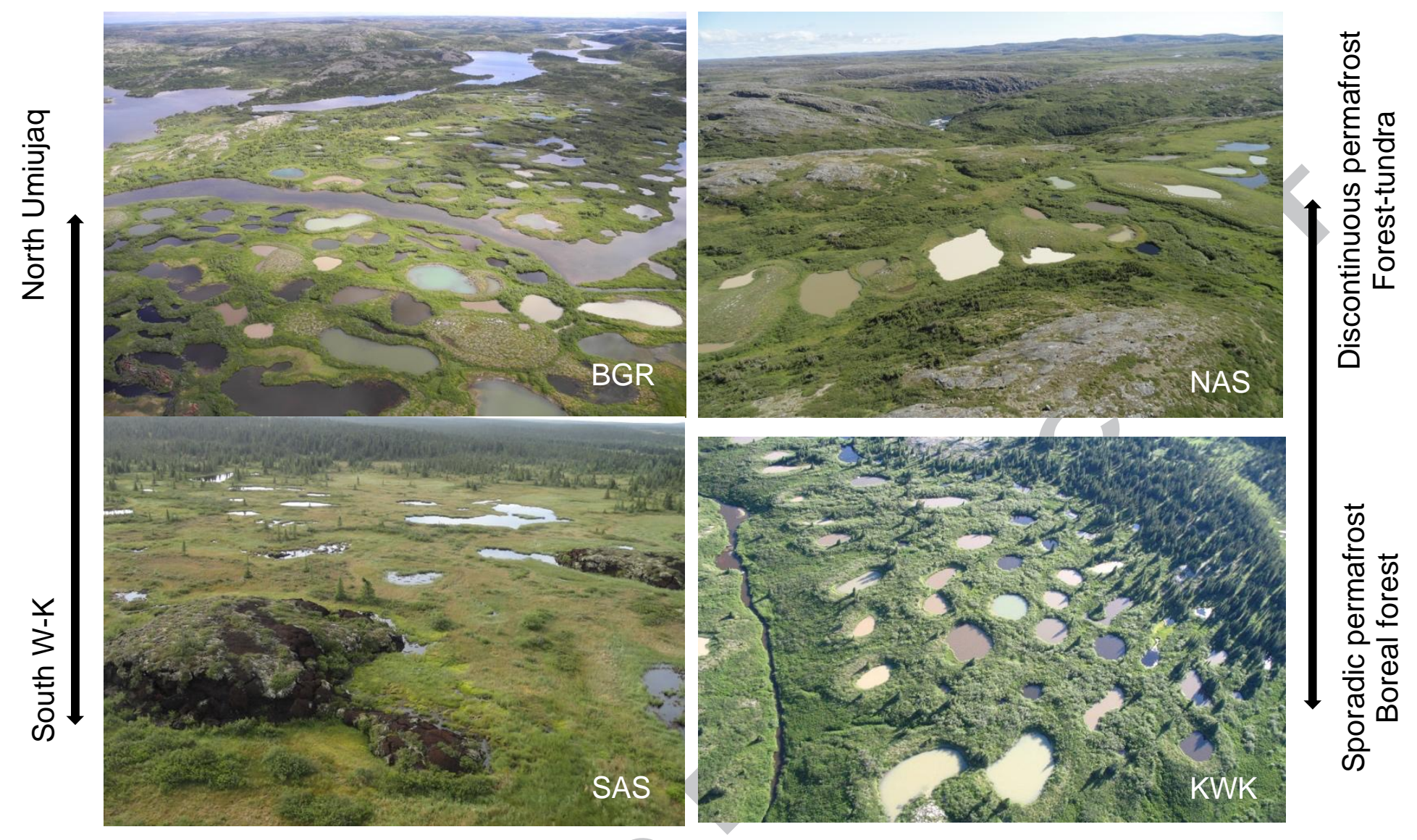

Fig. 2 Thermokarst lakes in Nunavik along north-south latitudinal, vegetation and permafrost gradients. 


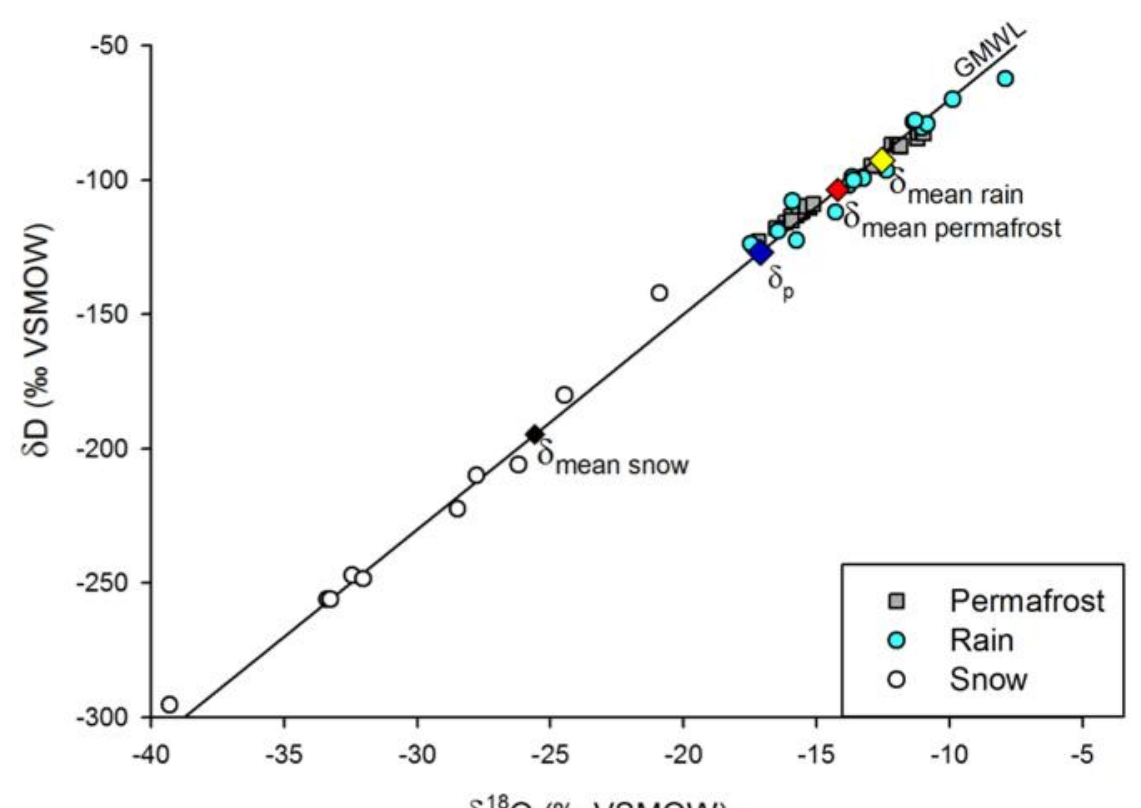

Fig. 3 $\delta^{18} \mathrm{O}(\% \circ \mathrm{VSMOW})$ Isotope compositions of snow, rain and permafrost relative to GMWL $\left(\delta \mathrm{D}=8 \delta^{18} 0+10\right.$, Craig 1961).

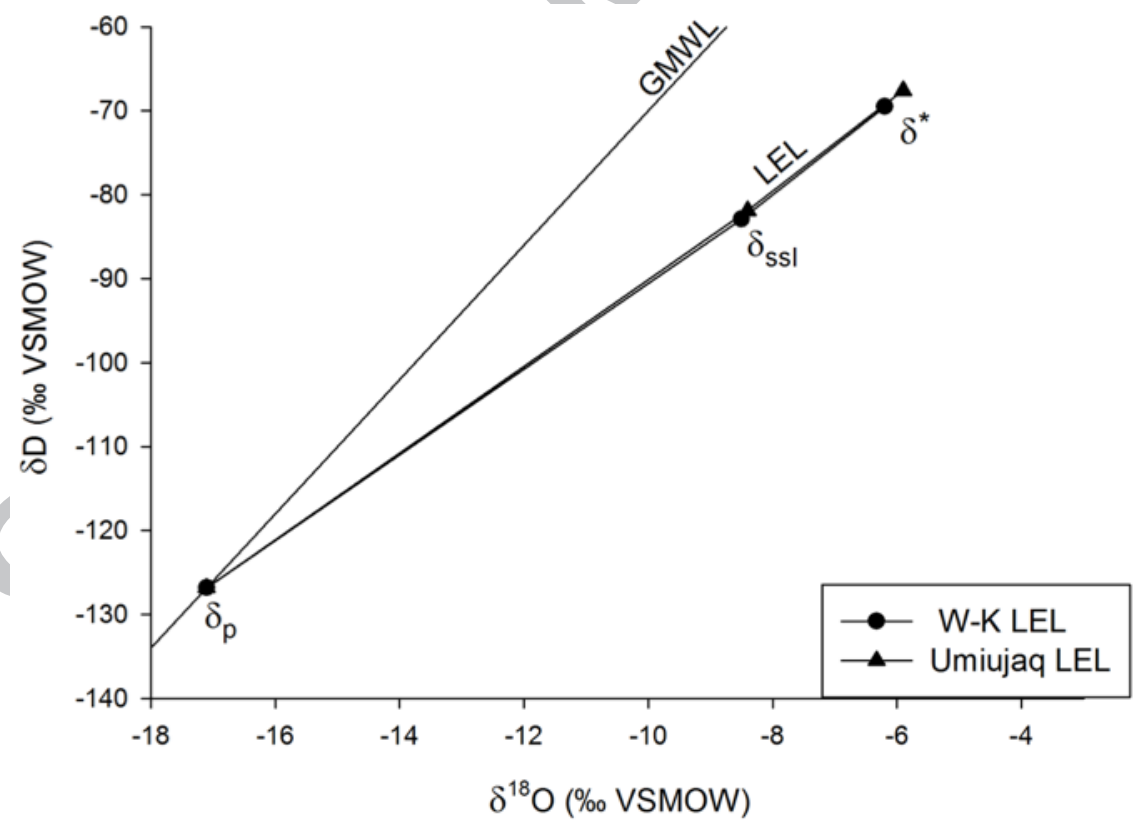

Fig. 4 Isotope frameworks for Nunavik lakes based on 3-year mean values of $\delta_{\mathrm{SSL}}$ and $\delta^{*}$. The two predicted LELs (W-K and Umiujaq) are anchored at $\delta_{\mathrm{p}}$, calculated from data presented in Table 5. 

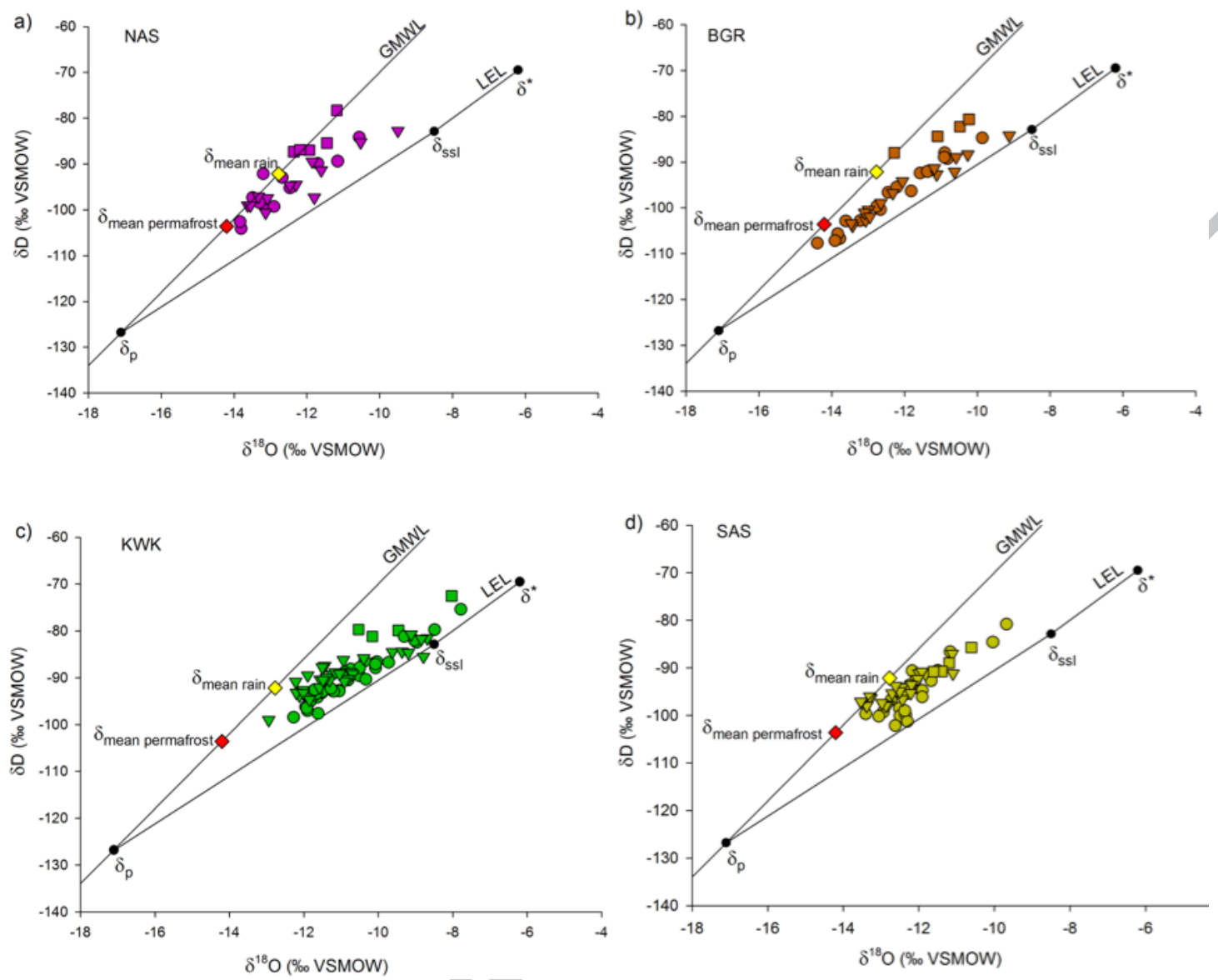

Fig. 5 Isotope composition of lakes sampled in 2012 (square), 2013 (circle) and 2014 (triangle) for each site a) NAS, b) BGR, c) KWK and d) SAS, superimposed on the 3-year mean W-K isotope framework (Fig. 4). The red diamond on the GMWL is the mean permafrost isotope composition (-14.20\% for $\delta^{18} \mathrm{O},-103.59 \%$ for $\delta \mathrm{D}$ ), and the yellow diamond represents the mean summer rain isotope composition $\left(-12.77 \%\right.$ for $\delta^{18} \mathrm{O},-92.16 \%$ for $\left.\delta \mathrm{D}\right)$. 

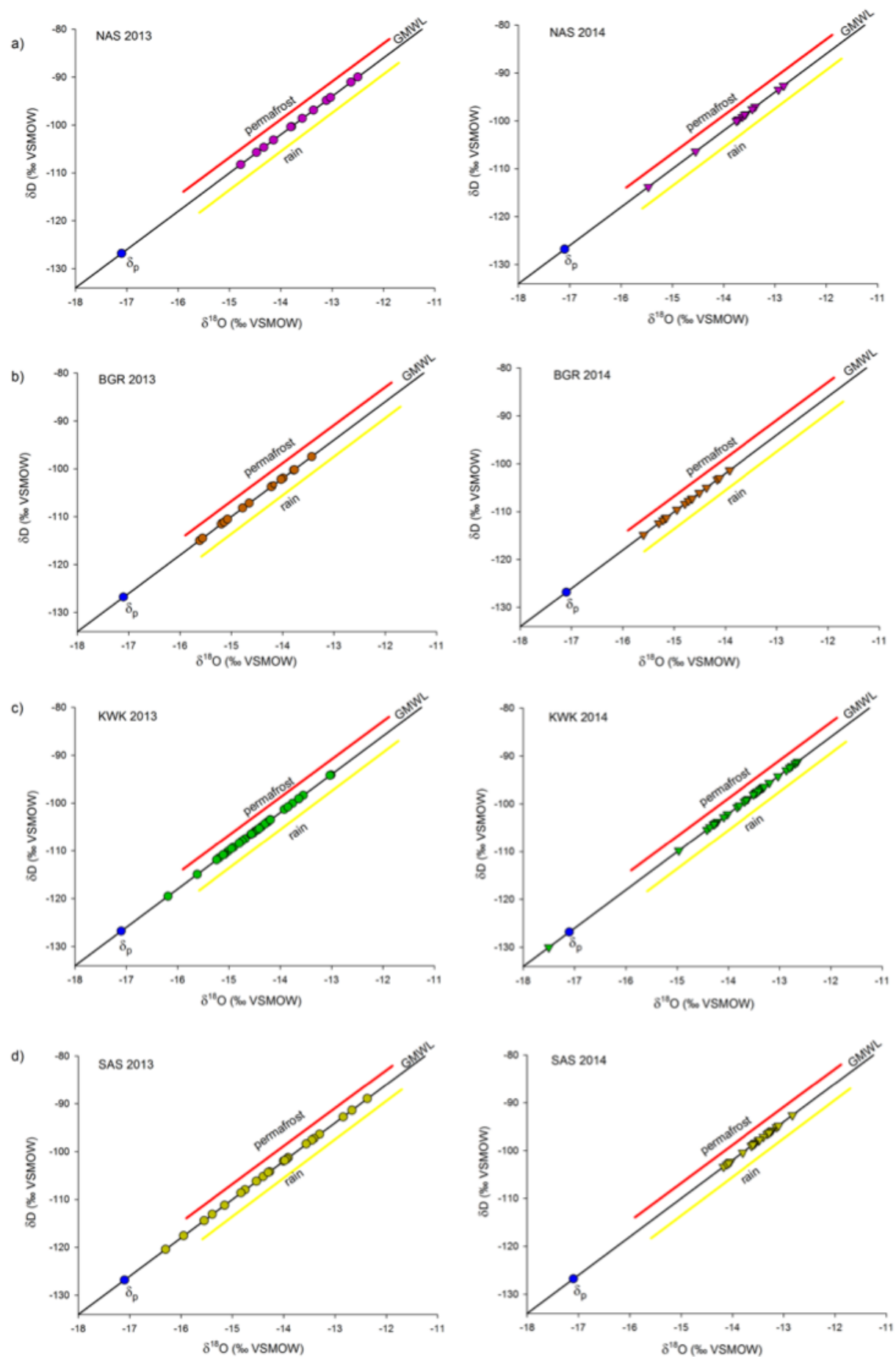


\section{ACCEPTED MANUSCRIPT}

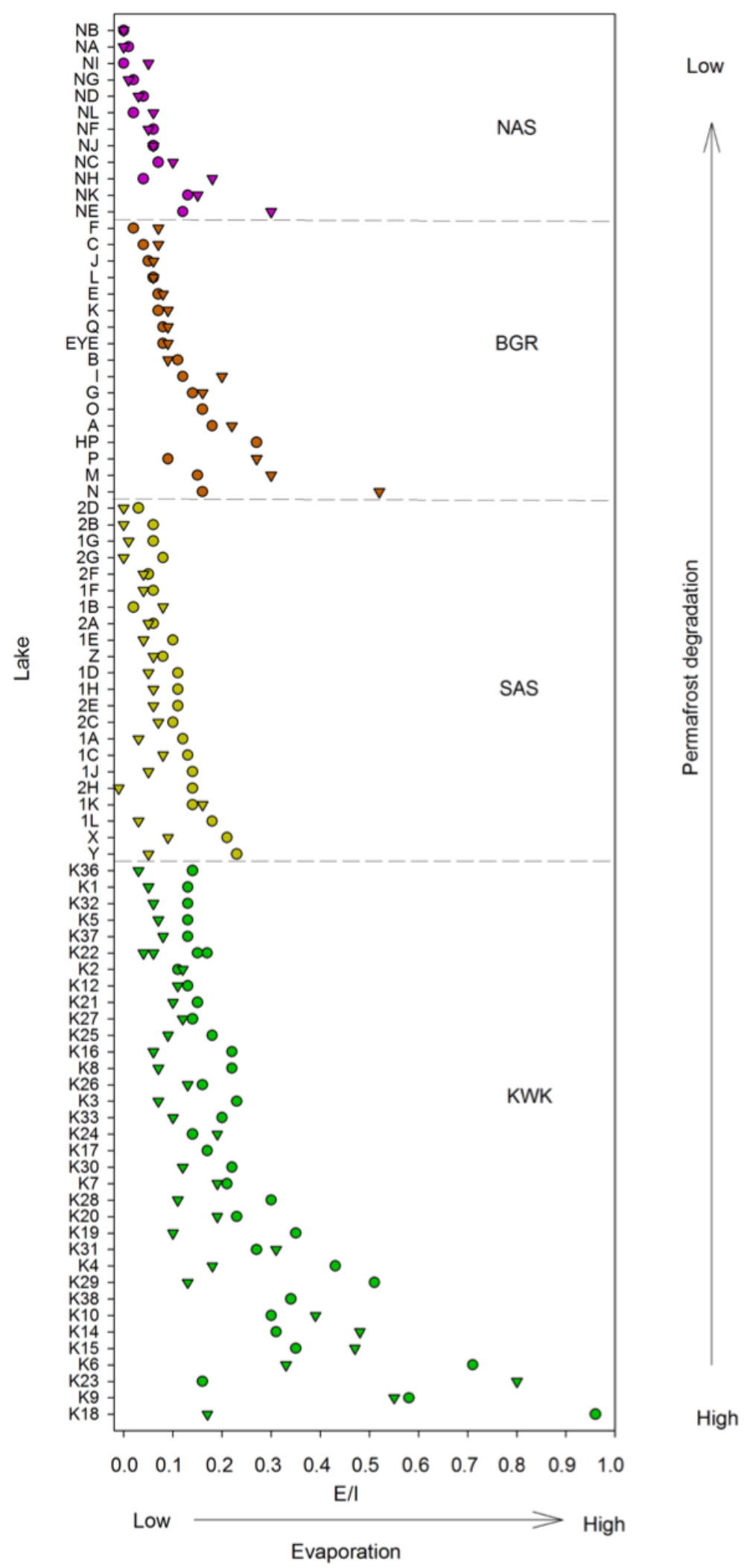

Fig. 6 Distribution of $\delta_{1}$ values for lakes sampled in 2013 (circle) and 2014 (triangle) for each site a) NAS, b) BGR, c) KWK and d) SAS. Isotope ranges for rain (yellow line) and permafrost (red 
line) are also shown. These ranges lie on the GMWL (Fig. 3), but are offset here for graphic purposes only. 
Fig. 7 Calculated E/l ratios for all lakes in 2013 (circle) and 2014 (triangle). Vertical and horizontal arrows illustrate gradient in permafrost degradation and water loss through evaporation, respectively. 
Table 1. Examples of recent studies incorporating stable isotope mass balance of thermokarst lakes, including present study.

\begin{tabular}{ll}
\multicolumn{1}{c}{ Study } & \multicolumn{1}{c}{ Data } \\
\hline $\begin{array}{l}\text { 1. Anderson et al., } \\
2013\end{array}$ & $\begin{array}{l}\text { remote imagery / } \\
\delta^{18} \mathrm{O}_{\text {lake water }} / \\
\text { hydroclimatic parameters }\end{array}$ \\
& \\
$\begin{array}{l}\text { 2. Bouchard et al., } \\
\text { 2013 }\end{array}$ & $\begin{array}{l}\delta^{18} \mathrm{O}_{\text {lake water }} \text { and } \delta^{18} \mathrm{O}_{\text {cellulose }} / \\
\text { lake surface sediments / } \\
\text { catchment vegetation gradient }\end{array}$
\end{tabular}

1. Anderson et al.,

$\delta^{18} \mathrm{O}_{\text {lake water }} /$

hydroclimatic parameters

Yukon Flats (Alaska, USA) /

discontinuous permafrost

Old Crow Flats (Yukon, Canada)

Hudson Bay Lowlands (Manitoba,

Canada) / continuous permafrost

Northeastern Alberta (Canada) / continuous and discontinuous permafrost

$\delta^{18} \mathrm{O}_{\text {lake water }}$ and $\delta \mathrm{D}_{\text {lake water }} /$ land cover distribution
3. Gibson et al., 2015

4. Turner et al., 2014 lake and watershed area

$\delta^{18} \mathrm{O}_{\text {lake water }}$ and $\delta \mathrm{D}_{\text {lake water }} /$
Old Crow Flats (Yukon, Canada) / continuous permafrost
Key results
1. Rainfall, snowfall, river and groundwater are the water sources for most YF lakes; some lakes are sourced by snowmelt and/or permafrost thaw.

2. Lake reductions are due to moisture deficits and greater evaporation.

1. Shallow lakes located in lowrelief, open tundra terrain are susceptible to desiccation by evaporation when snowmelt runoff is low.

2. Recent extremely dry conditions may be unprecedented in the past $\sim 200$ years.

1. Bog cover and permafrost thaw are dominant hydrologic drivers.

2. Thawing of permafrost is a main driver of differences in the hydrologic conditions between study sites.

1. Lake hydrological conditions are strongly influenced by catchment vegetation and physiography.

2. Future lake hydrological responses are varied.

Hudson Bay Lowlands (Manitoba, Canada) / continuous permafrost

Nunavik (Québec, Canada) / continuous, discontinuous and sporadic permafrost
1. Diverse hydrological responses of shallow lakes to $20^{\text {th }}$ century climate change.

2. Hydrological connectivity is key feature influencing lake hydrological response.

1. Rainfall and/or permafrost thaw are principal lake water input sources

2. Maritime climate suppresses evaporative lake-level drawdown. 
Table 2. Meteorological data for 1960-2014 (i.e., long-term mean) and the three-year sampling period from the station at Whapmagoostui-Kuujjuarapik (W-K) airport (Environment Canada, 2015).

\begin{tabular}{ccccccc}
\hline Year & $\begin{array}{c}\text { Temperature } \\
\left({ }^{\circ} \mathrm{C}\right)\end{array}$ & $\begin{array}{c}\text { Rain } \\
(\mathrm{mm})\end{array}$ & $\begin{array}{c}\text { Snow } \\
(\mathrm{mm})^{*}\end{array}$ & $\begin{array}{c}\text { Total precipitation } \\
(\mathrm{mm})\end{array}$ & \multicolumn{2}{c}{$\begin{array}{c}\text { Relative humidity } \\
(\%)\end{array}$} \\
\hline $1960-2014$ & -5.6 & 405.2 & 234.0 & 633.2 & W-K & Umiujaq $^{\star *}$ \\
2012 & -2.3 & 476.3 & 201.3 & 678.3 & 80.4 & 79.5 \\
2013 & -3.1 & 391.6 & 247.1 & 642.1 & 79.4 & 77.2 \\
2014 & -3.4 & 575.2 & 228.0 & 803.2 & 77.2 & 77.9 \\
\hline
\end{tabular}

${ }^{*}$ Snow water equivalent

**Umiujaq airport (Environment Canada, 2015)

Table 3. Water isotope data from precipitation collected at CEN station in W-K. The date format is $\mathrm{DD} / \mathrm{MM} / \mathrm{YY}$ where two-digit numeric codes are provided for days, months and years, respectively.

\begin{tabular}{|c|c|c|c|}
\hline Date & Precipitation & $\delta^{18} \mathrm{O}(\% \circ \mathrm{VSMOW})$ & $\delta \mathrm{D}(\% \circ \mathrm{VSMOW})$ \\
\hline 09/09/13 & Rain & -13.8 & -102.0 \\
\hline $13 / 10 / 13$ & Rain & -11.0 & -80.6 \\
\hline $19 / 10 / 13$ & Rain & -10.8 & -79.3 \\
\hline $01 / 11 / 13$ & Snow & -9.9 & -67.0 \\
\hline $17 / 11 / 13$ & Snow & -16.5 & -119.0 \\
\hline $09 / 12 / 13$ & Snow & -15.9 & -107.8 \\
\hline $13 / 12 / 13$ & Snow & -20.9 & -142.1 \\
\hline $25 / 12 / 13$ & Snow & -17.5 & -123.7 \\
\hline 06/01/14 & Snow & -24.5 & -180.0 \\
\hline $13 / 01 / 14$ & Snow & -32.4 & -247.1 \\
\hline $23 / 01 / 14$ & Snow & -39.3 & -295.4 \\
\hline $05 / 02 / 14$ & Snow & -33.4 & -256.1 \\
\hline $12 / 02 / 14$ & Snow & -32.0 & -248.4 \\
\hline $21 / 02 / 14$ & Snow & -26.2 & -206.0 \\
\hline $18 / 02 / 14$ & Snow & -33.3 & -256.0 \\
\hline $19 / 02 / 14$ & Snow & -28.5 & -222.4 \\
\hline $07 / 03 / 14$ & Snow & -27.8 & -210.0 \\
\hline $30 / 04 / 14$ & Snow & -13.5 & -99.5 \\
\hline $09 / 05 / 14$ & Rain & -15.8 & -122.4 \\
\hline $10 / 05 / 14$ & Rain & -14.3 & -112.0 \\
\hline $01 / 07 / 14$ & Rain & -13.3 & -99.0 \\
\hline $02 / 07 / 14$ & Rain & -13.3 & -99.1 \\
\hline $03 / 07 / 14$ & Rain & -13.2 & -99.4 \\
\hline $01 / 08 / 14$ & Rain & -13.7 & -98.8 \\
\hline $02 / 08 / 14$ & Rain & -13.6 & -100.1 \\
\hline $13 / 08 / 14$ & Rain & -12.4 & -96.4 \\
\hline $25 / 08 / 14$ & Rain & -11.4 & -78.3 \\
\hline $26 / 08 / 14$ & Rain & -11.3 & -77.8 \\
\hline $27 / 08 / 14$ & Rain & -7.9 & -62.3 \\
\hline Mean & Rain & -12.5 & -93.4 \\
\hline Mean & Snow & -25.6 & -185.6 \\
\hline
\end{tabular}


$\delta_{\mathrm{p}} \quad-17.1 \quad-126.8$

Table 4. Water isotope data from permafrost meltwater obtained from permafrost cores at SAS and BGR.

\begin{tabular}{cccc}
\hline Permafrost sample & Depth $(\mathrm{cm})$ & $\delta^{18} \mathrm{O}(\%$ VSMOW $)$ & $\delta \mathrm{D}(\%$ VSMOW $)$ \\
\hline BGR-A & $72-76$ & -15.8 & -113.3 \\
BGR-A & $86-91$ & -17.3 & -123.9 \\
BGR-A & $110-115$ & -17.2 & -122.9 \\
BGR-A & $207-212$ & -16.2 & -115.9 \\
BGR-A & $258-263$ & -15.5 & -111.5 \\
BGR-A & $305-311$ & -15.3 & -110.3 \\
BGR-B & & & \\
BGR-B & $101-93$ & -15.7 & -112.2 \\
BGR-B & $107-111$ & -16.0 & -113.5 \\
BGR-B & $117-123$ & -16.0 & -111.8 \\
BGR-B & $140-146$ & -15.7 & -111.9 \\
BGR-B & $154-159$ & -15.9 & -115.2 \\
BGR-B & $185-191$ & -16.5 & -117.9 \\
BGR-B & $237-243$ & -15.4 & -109.7 \\
BGR-B & $275-280$ & -15.4 & -109.8 \\
& & -15.1 & -108.9 \\
SAS-A & $74-78$ & & \\
SAS-A & $100-106$ & -12.2 & -86.9 \\
SAS-A & $144-150$ & -12.0 & -86.9 \\
SAS-A & $198-204$ & -11.2 & -84.5 \\
SAS-A & $274-280$ & -11.9 & -87.6 \\
SAS-B & $72-77$ & -12.6 & -94.7 \\
SAS-B & $88-93$ & & -82.3 \\
SAS-B & $110-115$ & -11.2 & -81.4 \\
SAS-B & $160-165$ & -11.0 & -82.6 \\
SAS-B & $210-215$ & -11.1 & -87.2 \\
SAS-B & $292-297.5$ \\
Mean & & -11.9 & -94.7 \\
\hline & -12.9 & -12.9 & -14.2 \\
\hline
\end{tabular}


Table 5. a) Flux-weighted temperature and relative humidity from June to September 2012, 2013 and 2014, based on calculation of potential evaporation using Thornthwaite (1948), and using data from the meteorological stations at W-K and Umiujaq airports (Environment Canada, 2015). b) Measured and calculated parameters used to develop the isotopic framework.

a)

\begin{tabular}{ccccc}
\hline & \multicolumn{2}{c}{ Temperature $\left({ }^{\circ} \mathrm{C}\right)$} & \multicolumn{2}{c}{ Relative Humidity (\%) } \\
\hline 2012 & W-K & Umiujaq & W-K & Umiujaq \\
2013 & 11.5 & 10.7 & 80.4 & 79.5 \\
2014 & 10.0 & 8.8 & 79.4 & 77.3 \\
\hline
\end{tabular}

b)

\begin{tabular}{|c|c|c|c|c|c|c|c|c|c|}
\hline \multirow[b]{2}{*}{ Parameter } & \multicolumn{2}{|c|}{2012} & \multicolumn{2}{|c|}{2013} & \multicolumn{2}{|c|}{2014} & \multicolumn{2}{|c|}{ Mean } & \multirow[b]{2}{*}{ Equation } \\
\hline & W-K & Umiujaq & W-K & Umiujaq & W-K & Umiujaq & W-K & Umiujaq & \\
\hline $\mathrm{T}(\mathrm{K})$ & 284.7 & 283.8 & 283.2 & 281.9 & 284.6 & 283.5 & 284.2 & 283.1 & \\
\hline h (\%) & 80.4 & 79.5 & 79.4 & 77.2 & 77.2 & 77.9 & 79.0 & 78.2 & \\
\hline$a^{*}\left({ }^{18} O, D\right)$ & $1.0106,1.0948$ & $1.0107,1.0960$ & $1.0107,1,0969$ & $1.0108,1.0986$ & $1.0106,1.0951$ & $1.0107,1.0965$ & $1.0106,1.0954$ & $1.0107,1.0968$ & (A2, A3) \\
\hline$\varepsilon^{*}\left({ }^{18} O, D\right)$ & $10.6,94.9$ & $10.7,96.1$ & $10.7,96.9$ & $10.9,98.6$ & $10.6,95.1$ & $10.7,96.5$ & 10. $6,95.6$ & $10.7,97.1$ & (A4) \\
\hline$\varepsilon_{K}\left({ }^{18} \mathrm{O}, \mathrm{D}\right)$ & $2.8,2.5$ & $2.9,2.6$ & $2.9,2.6$ & $3.2,2.8$ & $3.3,2.9$ & $3.1,2.8$ & $3,2.7$ & $3.1,2.7$ & $(\mathrm{~A} 5, \mathrm{~A} 6)$ \\
\hline$\delta_{\mathrm{AS}}\left(\left(^{18} \mathrm{O}, \mathrm{D}\right)\right.$ & $-23.1,-175.1$ & $-23.2,-175.7$ & $-23.3,-176.3$ & $-23.4,-177.2$ & $-23.2,-175.2$ & $-23.3,-176.0$ & $-23.2,-175.5$ & $-23.3,-176.3$ & (A7) \\
\hline$\delta_{S S L}\left({ }^{18} \mathrm{O}, \mathrm{D}\right)$ & $-8.8,-84.1$ & $-8.7,-83.2$ & $-8.6,-82.7$ & $-8.1,-80.7$ & $-8.2,-81.9$ & $-8.3,-81.9$ & $-8.5,-82.9$ & $-8.4,-81.9$ & (A1) \\
\hline$\delta^{*}\left({ }^{18} \mathrm{O}, \mathrm{D}\right)$ & $-6.7,-72.2$ & $-6.5,-70.6$ & $-6.3,-69.6$ & $-5.4,-65.0$ & $-5.5,-66.8$ & $-5.7,-67.2$ & $-6.2,-69.5$ & $-5.9,-67.6$ & (A8) \\
\hline$\delta_{\mathrm{P}}\left({ }^{18} \mathrm{O}, \mathrm{D}\right)$ & $-17.1,-126.8$ & $-17.1,-126.8$ & $-17.1,-126.8$ & $-17.1,-126.8$ & $-17.1,-126.8$ & $-17.1,-126.8$ & $-17.1,-126.8$ & $-17.1,-126.8$ & Table 3 \\
\hline
\end{tabular}




\section{HIGHLIGHTS:}

- Water isotopes are used to characterize thermokarst lake hydrology in Nunavik, Canada.

- Rainfall and/or permafrost meltwater are the main lake water sources.

- Maritime climate enhances the hydrological resiliency of thermokarst lakes.

- Terrestrial carbon inputs from surface runoff are likely to increase in the future.

- Thermokarst lakes will persist and methane emissions are likely to increase. 